NBER WORKING PAPER SERIES

\title{
LIQUIDITY SHORTAGES AND BANKING CRISES
}

\author{
Douglas W. Diamond \\ Raghuram G. Rajan \\ Working Paper 8937 \\ http://www.nber.org/papers/w8937 \\ NATIONAL BUREAU OF ECONOMIC RESEARCH \\ 1050 Massachusetts Avenue \\ Cambridge, MA 02138 \\ May 2002
}

\begin{abstract}
We are grateful to Isabel Gödde and Nobu Kiyotaki for very helpful comments on an earlier draft, and to Steve Ross and participants at the NBER Economic Fluctuations meetings in February 2001 for helpful suggestions. We are grateful for financial support from the National Science Foundation and the Center for Research on Security Prices. Rajan also thanks the Center for the Study of the State and the Economy for financial support. The views expressed herein are those of the authors and not necessarily those of the National Bureau of Economic Research.

(C) 2002 by Douglas W. Diamond and Raghuram G. Rajan. All rights reserved. Short sections of text, not to exceed two paragraphs, may be quoted without explicit permission provided that full credit, including (C) notice, is given to the source.
\end{abstract}


Liquidity Shortages and Banking Crises

Douglas W. Diamond and Raghuram G. Rajan

NBER Working Paper No. 8937

May 2002

\begin{abstract}
Banks can fail either because they are insolvent or because an aggregate shortage of liquidity can render them insolvent. We show that bank failures can themselves cause liquidity shortages. The failure of some banks can then lead to a cascade of failures and a possible total meltdown of the system. Contagion here is not caused by contractual or informational links between banks but because bank failure could lead to a contraction in the common pool of liquidity. There is a possible role for government intervention. Unfortunately, liquidity problems and solvency problems interact, and can each cause the other. It is therefore hard to determine the root cause of a crisis from observable factors. The practical difficulty of determining the most appropriate intervention, as well as the costs of the wrong kind of intervention (such as infusing capital when the need is for liquidity) have to be traded off against the costs of a meltdown, which can be substantial. We propose a robust sequence of intervention.
\end{abstract}

Douglas W. Diamond

Graduate School of Business

The University of Chicago

1101 East 58th Street

Chicago, IL 60637

and NBER

d-diamond@uchicago.edu
Raghuram G. Rajan

Graduate School of Business

The University of Chicago

1101 East 58th Street

Chicago, IL 60637

and NBER

raghuram.rajan@gsb.uchicago.edu 
Many economists would agree that an important role of a central bank is to alleviate a liquidity shortage, because, if not addressed, it could lead to bank failures and perhaps even a banking crisis. For example, in his classic, Lombard Street, Bagehot (1873, p196-197) argued that in a

"time of panic [the Bank of England] must advance freely and vigorously to the public out of the reserve...And for this purpose there are two rules:- First. That these loans should be made at a very high rate of interest. ... Secondly. That at this rate these advances should be made on all good banking securities, and as largely as the public ask for them."

In contrast to this general acquiescence to liquidity support, few would advocate bailing out specific banks through capital infusions - witness Bagehot's view that liquidity loans should be made at high rates and against good collateral so that there is not even a hint of a subsidy. There appear to be at least two reasons for the difference in approach to a liquidity shortage and a solvency problem. First, when a bank fails because it is insolvent, it is felt that it has got its just deserts. A bailout might encourage moral hazard. Second, and perhaps more important, it is thought (perhaps more by academics than by practitioners) that a bank failure has no systemic consequences - the costs of failure are borne by its borrowers, depositors, investors, and managers alone.

It is this second point that we would like to dispute in this paper. For while it is well known that systemic illiquidity can cause bank failures, we show that the reverse phenomenon is also possible - bank failures can cause systemic illiquidity. This then suggests the possibility of a contagion of bank failures where a bank's failure subtracts liquidity from the system, and this negative spillover effect raises the likelihood of failure of other banks. It is possible that the entire system melts down making everyone worse off, even though it would survive intact if a few banks were recapitalized.

Let us describe the model to sketch how this happens. There is a single consumption good (we will also call this "cash") owned by potential investors. In addition, entrepreneurs have project ideas. Projects require an investment of consumption goods up front, and will pay off a 
larger amount of consumption goods, either quickly or after considerable delay. ${ }^{1}$ Projects are thus risky, but only in that the timing of when they pay off is uncertain. Projects also are illiquid in that only a specific entrepreneur can produce consumption goods from a specific project, and loans are illiquid in that only the initial lender has the specific collection skills to extract a repayment from the entrepreneur. Given our assumptions, the entrepreneur will need to borrow indirectly, through a bank. The bank will have to issue investors demand deposits so that they are confident they will get repaid even though the bank loans to entrepreneurs are illiquid - demand deposits are a commitment to repay (as in Diamond and Rajan (2001)). We now ask what happens if a number of projects are delayed so that the natural supply of consumption goods at the interim date is small, even though many depositors want to withdraw to consume.

If the number of delayed projects is not too large, banks and investors will not suffer greatly. A bank can raise new financing against delayed projects and pass that along to those who want to consume. The new financing will be available from entrepreneurs whose projects are timely, because they will have sufficient spare cash after repaying their debts. The bank's ability to commit to repay these new depositors will enables it to raise cash which it will use to repay old depositors. Thus existing consumption goods will be allocated efficiently via the bank.

Problems arise if too many projects are delayed. In that case, not only does the bank get paid less immediately, but also it may be able to borrow only a fraction of the future value of delayed projects (we explain why in the paper). As a result, the funds the bank can raise today against future cash inflows may be smaller than its immediate net liabilities - which we term a "solvency problem". In this case, potential new depositors (timely entrepreneurs with spare cash) will be unwilling to lend to the bank. At the same time, because few entrepreneurs are timely, there may also be fewer consumption goods in the economy than needed to pay existing depositors (and other claimants on the bank). This is a "liquidity problem".

\footnotetext{
${ }^{1}$ This could be thought of as a model of delays in harvest, or crop failure, that so plagued banking systems in the $19^{\text {th }}$ century. If the consumption good is commodity money or foreign exchange, the delay could be thought of as a postponement of exports.
} 
System wide illiquidity can make banks insolvent: With consumption goods in short supply, banks can be forced to harvest cash from more valuable, but illiquid, assets to meet the non-negotiable demands of depositors. They may also bid up interest rates to attract deposits from other banks. While increases in interest rates will reduce the demand for liquidity, some banks will not be healthy enough to let this process run its course. Instead, they will become insolvent and be run.

But insolvency and runs can themselves increase illiquidity in the system: Because bank assets are not readily transferable (a bank's role in our model is to hold illiquid assets to maturity), the bank will squeeze all the consumption goods it can get immediately out of its nearterm liquid assets, a transformation process that not only reduces liquidity in the system, but also potentially draws liquidity away from the rest of the system. By subtracting from the common pool of consumption goods that would be available to other banks, a run can thus exacerbate liquidity shortages. This can cause contagion, not because runs cause a panic to spread, nor because bank runs signal information about fundamentals (see Chari and Jagannathan (1988)), nor even because banks have deposits in each other (see Smith (1991), and Allen and Gale (2000)) but because runs themselves change fundamentals (the excess demand for liquidity). Also, because the excess demand for liquidity can be non-monotonic in the interest rate, multiple interest rate equilibria, with different fractions of the banking sector becoming insolvent, are possible.

It is important to note that contagion arises precisely because of the special features of banks that we think are central to their functions: Non-renegotiable demand depositors run, creating an inelastic demand for cash, and run banks have to squeeze cash out of non-transferable loans in socially inefficient ways, thereby imposing an externality on the system. The social inefficiency of runs, and the consequent potential for contagion, suggests that a central authority may choose to intervene to attempt to stop them. In addition, a government might intrinsically want to avoid very costly banking crises even if by doing so, it helps only part of the population. 
We characterize interventions as some combination of providing liquidity to the banking system and providing capital (value) to individual banks. To intervene effectively, however, it is important to understand the precise cause for the bad outcome. Unfortunately, the root cause is difficult to identify from the observable symptoms of the problems. For instance, bank insolvencies can be caused by a liquidity problem, while high risk less real interest rates (an indication of a shortage of liquidity) can stem from a solvency problem, or even an attempt to solve a solvency problem. Furthermore, when we also account for where the resources to finance intervention come from, we find there are few benign interventions. Interventions are almost always reallocations of property rights.

We do not study the ex-ante desirability of a policy of intervention - though we can point to seemingly worthwhile interventions that are not only harmful ex post, but also ex ante (see Diamond and Rajan (2002) for an example based on our model). What is clear, however, is that in contrast to Bagehot [1873], Thornton [1802] and Goodfriend and King [1988], we do not see a reason to limit interventions that are intended to prevent systemic or contagion problems to liquidity provision. Sometimes it may make sense to lend freely at a low interest rate. At other times, it may make sense to lend to a bank against poor security. Both interventions inject capital. We do, however, find circumstances where inappropriate infusions of capital can lead to worse outcomes than no intervention at all. Thus liquidity infusions have the virtue that they never do a great deal of harm, and may well be the first step a central bank should take in the absence of more detailed knowledge.

The rest of the paper is as follows. We lay out the framework in section I, and solve the model in section II. Section III examines the effects of various kinds of interventions, after which we conclude. 


\section{Framework}

In what follows, we describe the economy, entrepreneurs, investors, and why banks are special in intermediating finance. This section provides a micro-foundation for the results in the balance of the paper, adapting the models from our previous research (Diamond and Rajan (2000, 2001a, 2001b)).

\subsection{Agents and Projects.}

Consider an economy with entrepreneurs, bankers, and investors. The economy lasts for two periods and three dates -- date 0 to date 2 . There are two kinds of goods in the economy consumption goods and machinery. Each entrepreneur has a project idea. The project requires up to 1 unit of consumption goods at date 0 , which the entrepreneur then converts to machinery. There is uncertainty up front about when the machinery will be ready to produce consumption goods. It could produce $C$ units (unless otherwise specified, quantities are per unit invested) either "early" - at date 1-or "late"-at date 2. Once a machine produces consumption goods, it becomes worthless.

Even if the machinery is ready to produce at a particular date, the entrepreneur has to be the one using it for $C$ units to be produced. In other words, production requires his specific human capital skills. There are two other ways to make use of the machinery. The first is to restructure the project to focus on the near-term production of consumption goods. This can be done at any time until date 1. Restructuring may involve salvaging the consumption goods that have not yet been converted to machinery or abandoning the uncertain technology in favor of tried and tested technologies that can produce goods quickly and with certainty. A project, when restructured, produces $c_{1}>0$ immediately, and $c_{2} \geq 0$ at date 2 . Thus a restructured project will produce more goods before date 2 than a project that is known to be late.

A second alternative is to produce with the machinery in a way that is not as dependent on the entrepreneur. This may involve finding an entrepreneur who has similar skills to those possessed by the original entrepreneur, or abandoning some aspects of the original project that 
were particularly dependent on the original entrepreneur's skills. Let us call this alternative "replacement," even though the range of possible actions may be broader than simply replacing the entrepreneur. What is important is that this involves retaining much of the original strategy so that the timing of cash flows is unchanged. Specifically, when the original entrepreneur is replaced, the project produces $\gamma \mathrm{C}$ on the date it would have produced with the original entrepreneur, where $\gamma<1$.

There are two differences between restructuring the project to squeeze more out of it in the short run and replacing the entrepreneur. First, though both result in a loss of surplus because

$$
c_{1}+c_{2}<1<\gamma C<C
$$

replacing the entrepreneur generates more goods in expectation since it preserves the original intent of the investment. Second, restructuring produces some goods immediately if the project is known to be late, while replacement produces none. But there is also a similarity: Not everyone other than the entrepreneur has the skills to restructure the project or find his replacement. We will describe shortly who can acquire these skills.

\subsection{Endowments.}

Entrepreneurs do not have any consumption goods (cash) to finance their projects. ${ }^{2}$ There are a large number of investors at date 0 , each with a fraction of a unit of endowment of the consumption good. Investors can either store their consumption good (which generates 1 unit at date $\mathrm{t}+1$ for every unit stored at date $\mathrm{t}$ ) or invest in projects via banks, an institution we will describe shortly (there is no prohibition on direct lending-- it simply turns out not be feasible). The aggregate endowment of investors at date 0 is less than the total number of project opportunities, so the economy is short of investment capital. All project opportunities that are not funded at date 0 expire unexploited.

We assume that all date- 0 investors have a very high discount rate for consumption at date 2 relative to consumption at date 1, implying that they want as much access to date 1 
consumption as possible. Bankers and entrepreneurs value consumption at either date 1 or 2 equally. None of the results are qualitatively affected by investors and bankers having different horizons. ${ }^{3}$ All agents are risk-neutral.

\subsection{Banks}

A banker is an agent who, for a subset of the date- 0 project opportunities in his immediate neighborhood, can acquire, through lending, the specific skills needed to restructure projects or replace entrepreneurs. For example, a banker may have knowledge of local labor and goods markets. During the course of lending to a nearby project, he learns how the entrepreneur puts it together, and what it takes to run it. Project experience combined with his local knowledge allows him to find alternative uses, or users of the assets, easily. Thus while the local banker can generate as much value as the entrepreneur by restructuring or replacing, all others get zero doing so. Because only one banker has knowledge of each local market, each banker has a local monopoly in lending. ${ }^{4}$

The local lending markets faced by each bank are identical at the time of lending at date 0 , but become heterogeneous at date $1 / 2$ in that, in each market, a different fraction of the funded projects turn out to be early. Therefore, at date $1 / 2$ the aggregate state is fully characterized by the realization of the fraction of projects that are early for each bank $i, \alpha^{\mathrm{i}}$. It will be convenient to work on a per project basis with the realized distribution of $\alpha^{i}$. Without loss of generality, let us assume that $\alpha^{\mathrm{i}}$ is increasing in the index $i$ and the realized distribution in aggregate state $s$ is $\mathrm{F}^{\mathrm{s}}\left(\alpha^{\mathrm{i}}\right)$. We assume in the derivations that there are no mass points, but these are easily handled,

\footnotetext{
${ }^{2}$ There, however, is no fiat money in this economy. The consumption goods could be thought of as commodity money, or foreign exchange, if we are willing to accept that some fraction (1- $\left.c_{1}\right)$ is used up, or leaves the economy, in the process of investment.

${ }^{3}$ If we assume that both the bankers and date- 0 investors have the same discount factor at date 1 for date 2 consumption of $\frac{c_{1}}{\gamma C-c_{2}}+\varepsilon$, where $\varepsilon$ is a small number, all our results are unchanged. The higher the common discount factor, the lower the interest rate at which liquidity problems are resolved. Nothing else changes in the model.

${ }^{4}$ All this assumption does is to ensure that the requirement of local knowledge - a form of talent -prevents banking from becoming either a monopoly or being subject to free entry.
} 
and we will provide examples with discrete distributions. The date- 0 probability of the aggregate state $s$ is $p^{s}$. The timeline for a project and the loan to it is in figure 1 .

\subsection{Financing.}

Since they cannot acquire the specific skills to extract repayment, investors cannot lend directly to entrepreneurs. ${ }^{5}$ Therefore, they can either store or lend to banks. A bank that obtains funds then lends to local entrepreneurs.

The source of friction in financing in our model is that any agent can commit explicitly to contributing his specific skills to a venture only for a short period (in the spot market) but not in the future. This then limits how much any agent can commit to repay in the future, for money borrowed today. Once the future arrives, the agent can threaten to quit and not contribute his skills unless the payment is negotiated down. The wedge between what the agent can generate with the asset, and what he can commit to pay out to lenders, is a measure of the illiquidity of the asset.

In particular, we consider financial contracts that specify the borrower owns the asset he has the specific skills to operate. In the case of borrowing by the entrepreneur, the asset is the machinery; in the case of borrowing by the bank, the asset is the loan it has made. If the borrower fails to make a required payment to the lender and offers an alternative schedule of payments to the one initially contracted, the lender can (1) accept the renegotiated contract, or (2) take possession of the asset and choose to do what he pleases with it. If the lender accepts, the borrower makes any immediate payment due according to the new schedule and continues to possess the asset. The particulars of this contract and the particular friction are from Hart and Moore (1994), but our ideas hold more generally.

Example 1: Suppose that it is date 1, the project turns out to be early, and at date 0, the entrepreneur promised to pay $\mathrm{P}_{1}=\mathrm{C}$ at date 1 . Come date 1 , the entrepreneur knows the banker can obtain only $\gamma \mathrm{C}$ by replacing him. As a result, he will offer to pay only $\gamma \mathrm{C}$. The banker will accept

\footnotetext{
${ }^{5}$ Even if investors could acquire specific skills, direct lending is unprofitable here since the investor needs to consume at date 1 and cannot transfer his skills to anyone who takes over the loan. As a result all
} 
since he cannot do any better by refusing. The entrepreneur thus can generate $\mathrm{C}$ in cash, but can commit to only pay out $\gamma \mathrm{C}$. The difference (the lack of pledgeability) stems from his inability to commit his specific operating skills.

Lenders other than the banker have no ability to replace the entrepreneur or restructure the project. As a result, they cannot enforce any repayment on their own. The banker's specific skills enable him to collect more, so we will refer to these skills as collection skills. We assume that the banker needs constant close contact with the entrepreneur to maintain his collection skills so that if he sells his financial claim on the project, or if it is seized from him, he loses his skills the next period. This assumption simplifies the analysis but is not critical. ${ }^{6}$

\subsection{Bank Liabilities: Deposits.}

While the banker can collect more on the loan to the entrepreneur than other lenders can, it is not obvious that he can pass through what he collects to those who finance him. The reason is that, in the same way as the entrepreneur, he can always turn around and extract rents from those who lent to him in return for deploying his collection skills on their behalf. In Diamond and Rajan (2001 a), however, we show that if, for example, the banker expects to collect $\gamma \mathrm{C}$ from a late project at date 2 with certainty, he can raise the full value of expected collections (discounted at market rates) at date 1 without suffering any additional discount for his specific skills. He does so by issuing demand deposits of face value $\gamma \mathrm{C}$ to those with cash to invest at date 1 .

A demand deposit allows the depositor to withdraw a pre-specified amount $d$ at any time. When the depositor decides to withdraw, he joins a line with other depositors who decide to withdraw at that time. If the banker does not pay him the full promised nominal repayment $d$, the depositor has the right to seize bank assets (consumption goods + loans) equal in market value (as determined by what the assets would fetch in a sale by the banker) to $d$. Depositors get paid or

projects funded directly by investors will have to be restructured at date 1 . Since $c_{1}+c_{2}<1$, direct funding would be dominated by storage.

${ }^{6}$ In Diamond-Rajan (2001a) we get similar results when the financier retains skills no matter what happens to the ownership of the financial claim. 
seize assets based on their place in line. ${ }^{7}$ Therefore if bank assets are insufficient to pay all depositors, the first one in line gets paid in full while the last one gets nothing.

Here is why the banker can commit to repay depositors fully: If the banker should offer depositors less than $d$ at date 2, then each depositor has the unilateral incentive to run to the bank to get paid in full, whenever other depositors have not done so first. Once the run starts, the banker cannot wait till the entrepreneur produces cash at date 2 to obtain the money to repay deposits. He will have to restructure the project immediately, and use the money thus obtained to pay depositors. But this will be insufficient to pay all because $c_{1}+c_{2}<\gamma C$ from (1.1). As a result, all the projects will be restructured, and all the money paid out, and the banker's rents will be driven to zero. Fearing the run, and the consequent loss of assets and rents, the banker will pay out the full promised amount, $\gamma \mathrm{C}$, at date 2 . In short, by issuing demand deposits, the banker can commit to pay in full, even though his specific skills are needed to collect. The banker can then borrow the present value of $\gamma \mathrm{C}$ at date 1, without having to accept any discount (see Diamond and Rajan (2001a) for details). Essentially, we have a rationale for the sequential service constraint underlying bank deposits that is often assumed in the literature (though see Wallace (1988) for a complementary 'limited participation in markets' explanation which could be incorporated into our approach without changing our results).

Since the banker (or the entrepreneur) can threaten to renegotiate at any point after the deposit is made, deposits must be demandable at any time, although consumption is needed only on dates 1 or 2 . Therefore, deposits are demandable not so much to satisfy the uncertain consumption needs of depositors (though, as we will see, they end up doing that) but so that the banker can commit, via the collective action problem created by deposits, not to extract rents from depositors.

\subsection{Bank Liabilities: Capital}

The rigidity of deposits can be costly if there is any uncertainty: A drop in asset values, even if

\footnotetext{
${ }^{7}$ An equivalent assumption to depositors seizing loans is that they demand cash and the bank is forced to sell loans at their market value to third parties to meet cash demands. The net effect is the same.
} 
due to no fault of the banker's, will precipitate a destructive run. The bank can also issue softer claims called "capital". They are paid after all deposits are paid out, and unlike deposits, can be renegotiated because they do not suffer from a collective action problem. The amount paid out on capital will then depend on bargaining between the bank and capital. We assume it takes a simple form. The banker makes an offer of what he will pay net of deposits. If the capital accepts, this is what is paid. If capital instead rejects, one of them (chosen with equal probability) gets to make a take-it-or-leave-it offer to the other. ${ }^{8}$

We will assume that for a continuing bank at each date, capital is required to be, at minimum, a fraction $k$ of the pledgeable (market) value of the bank's liabilities (nothing requires this fraction to be constant over time). Given the capital requirement, deposits can represent at most a fraction $\frac{(1-k)}{1+k}$ of liabilities and therefore only a fraction $1 /(1+k)$ of the total date-t value of the bank can be pledged to outsiders (capital plus deposits) at date $\mathrm{t}-1$. The banker absorbs the rest as rent (which increases in $k$ ). The advantage of capital is that payments to it adjust to the value of the bank. So if there is uncertainty about bank asset values, the bank can avoid destructive runs if it issues some capital in lieu of deposits. The disadvantage is that the banker, unlike with deposits, will absorb some rents. Trading off the destruction in value from runs against the loss in value because the banker retains rents, we find that when bank asset values are uncertain the banker may be able to pay out the most in expectation at a non-zero level of capital (see Diamond and Rajan (2000)). Thus our capital "requirement" could be thought of as the optimal bank response to un-modeled residual uncertainty about bank asset values. Since there is no uncertainty about the value of storage, we assume no capital need be held against it. ${ }^{9}$

\footnotetext{
${ }^{8}$ This bargaining game gives capital some bargaining power. The precise amount of bargaining power, provided it is non-zero, does not affect the results qualitatively. We have assumed lenders have no bargaining power only for notational simplicity.

${ }^{9}$ Another, less aesthetic, rationale for capital is that it is simply required by the authorities. More generally, all we require is that no capital structure would allow the bank to pledge all of future loan collections to outsiders.
} 


\subsection{Sequence of Events in the Economy.}

We have now described borrowing by the entrepreneur, and the nature of bank liabilities. Before we embed both in the full-fledged model, let us describe the sequence of actions (see Figure 2). Banks compete for investors' endowments by issuing a mix of deposits and capital at date 0 . Since consumption goods are in short supply relative to projects, investors will be promised the maximum that can be pledged to them, and will invest so long as their opportunity rate of return (of storage) is met.

Since all banks are identical at date 0 , they will choose to issue the same quantity of demand deposits, $d_{0}$ (all quantities are normalized on a per loan basis). Given the distribution of anticipated outcomes, there will be an associated amount of capital each bank can issue. The bank can then lend the money to entrepreneurs in its neighborhood or invest in storage. Let us assume initially that the bank does not store if it lends (we will show later that this is the case.) The bank will charge the maximum possible on each loan it makes. Since entrepreneurs can pledge to pay, at maximum, $\gamma \mathrm{C}$ when they produce, the bank can extract the maximum possible if the loan is repayable on demand and has a face value of $\gamma \mathrm{C}$.

At date $1 / 2$, everyone learns what fraction $\alpha^{\mathrm{i}}$ of a bank $i$ 's projects are early. If depositors anticipate the bank will not be able to pay them at date 1, given the bank's state and aggregate liquidity conditions, they will run immediately. Otherwise, they will wait till date 1 and demand payment in an orderly fashion.

If their bank survives, the entrepreneurs with early projects will repay the bank $\gamma \mathrm{C}$ at date 1 (leaving them with $(1-\gamma) \mathrm{C}$ to invest as they will), while entrepreneurs with late projects will default. Depending on the prevailing rate and its need for funds, the bank will then decide how to deal with each late project - whether to restructure it if cash is needed at date 1 , or perhaps get greater long run value by rescheduling the loan payment till date 2 and keeping the project as a going concern. The bank uses repayments from entrepreneurs whose projects are early, from 
restructured late projects, and from cash reinvested in the banks by early entrepreneurs to repay investors at date 1 .

Entrepreneur and date-0 investor decisions are simple. Entrepreneurs will pay if their projects mature, and will invest any spare cash at date 1 in solvent banks (so long as the prevailing rate weakly exceeds storage). Date- 0 depositors will run at date $1 / 2$ if they anticipate their bank will not be able to raise enough to pay them off at date 1 . They will come in an orderly fashion for their money at date 1 otherwise. Date- 0 capital will bargain with the solvent bank at date 1 and get its due. So the principal issue to be determined is the behavior of the banks and the interest rates that will prevail in the economy.

\section{Solving the Model.}

We first determine how much bank $i$ can raise to pay claimants at date 1, taking its actions with respect to its portfolio of late loans (i.e., restructure or continue) as given. We then determine what actions will be taken given the interest rate and the amount it needs to raise. We then discuss an example of equilibrium outcomes to fix ideas, before proceeding to a discussion of the equilibrium.

\subsection{How much can the bank raise at date 1 to repay date- 0 investors?}

Let $r$ be the equilibrium gross interest rate (total rate of return) between date 1 and date 2 in a particular aggregate state $\mathrm{s}$. Start first with a bank $i$ that has survived till date 1 . Let the banker restructure $\mu^{\mathrm{i}}$ of his late projects. Then the amount he can raise at date 1 to pay off his liabilities is

$v\left(\alpha^{i}, \mu^{i}, r\right)=\alpha^{i} \gamma C+\mu^{i}\left(1-\alpha^{i}\right)\left(c_{1}+\frac{c_{2}}{r}\right)+\left(1-\mu^{i}\right)\left(1-\alpha^{i}\right) \frac{\gamma C}{(1+k) r}$

The first term on the right hand side is the amount repaid by the $\alpha^{\mathrm{i}}$ early entrepreneurs whose projects mature at date 1 . The second term is the amount obtained by restructuring late projects. 
Note that the bank obtains $c_{l}$ directly in consumption goods from the restructuring, while it obtains $c_{2} / r$ from selling the date-2 portion of the restructured project for cash (the buyers are early entrepreneurs who have cash left over after repaying their bank, or banks that have excess cash after paying out to date- 0 investors). The third term is the amount the bank can raise against late projects that are allowed to continue without interruption till date 2 (the investors are again early entrepreneurs and banks with excess cash). The amount the bank can raise at date 1 against a continued project is lower than what it expects to collect from the entrepreneur at date 2 -because $\mathrm{r}$ may be greater than 1 , and because the bank has to maintain capital against the continued project which, unlike deposits, leaves it a rent at date 2 .

If the bank is not expected to be able to pay depositors at date 1 , then as soon as information about its condition (i.e., $\alpha^{\mathrm{i}}$ ) is revealed, its depositors will run. Even though greater liquidity would be available to depositors if they could wait, and even though depositors have no need to consume before date 1 , the anticipated demise of the bank forces them to rush for payment before others. Since bank assets are illiquid and cannot be transferred without restructuring, and the run occurs before date 1 , the bank will restructure all projects, even early ones, in a futile attempt to pay off depositors as they come to withdraw. ${ }^{10}$ The bank produces liquidity in a very inefficient way, restructuring early projects even though no one can consume before date 1 . Depositors, however, leave it no alternative. The value paid out to depositors will be the entire market value of the bank's assets, which is

$$
c_{1}+\frac{c_{2}}{r}
$$

\footnotetext{
${ }^{10}$ When a bank is run and it runs out of cash reserves, it can either allow depositors to seize project loans equivalent in market value to what they are owed, or restructure projects and pay the resulting funds out to depositors. In either case the bank's rents will be zero, but the bank will have a weak preference for restructuring rather than allowing depositors to seize loans. The reason is that the market value of seized loans is the value from restructuring them (the best alternative use of the project assets) less the strictly positive rent the bank is anticipated to charge for restructuring. Thus the market value of loans is less than the value from restructuring the underlying projects. It stands to reason then that the banker will weakly prefer restructuring loans when faced with a run, and if there is any chance that the queue of depositors will not exhaust the bank's assets, this preference will be strict. Thus, when run, the banker will restructure all projects.
} 
and all projects will be restructured.

The only choice variable going into date 1 for a bank is what fraction of late projects it should restructure (or equivalently, what fraction it should continue by raising deposits) to meet its liabilities. We now determine the bank's preferences between restructuring and continuing taking the prevailing rate as given.

\subsection{Restructuring versus continuing late projects.}

If a solvent banker chooses to continue financing a late project, he will collect $\gamma \mathrm{C}$ at date 2. If he restructures it, he will get $r c_{1}+c_{2}$ at date 2 . Therefore, the banker gets more at date 2 by continuing a project if ${ }^{11}$

$$
r<\bar{R}=\frac{\gamma C-c_{2}}{c_{1}}
$$

However, the banker also needs to raise enough money to pay off his maturing date-1 liabilities.

Given that he has to maintain capital requirements going forward, he can raise $\frac{\gamma C}{(1+k) r}$ in

deposits and capital at date 1 against the prospective payment from late entrepreneurs. The bank

can obtain $c_{1}+\frac{c_{2}}{r}$ by restructuring late projects. So continuation fetches more date- 1 funds than

$$
\text { restructuring only if } \quad r<R=\frac{\frac{\gamma C}{(1+k)}-c_{2}}{c_{1}}
$$

By inspection, $R<\bar{R}$. Therefore, if $\mathrm{r}<\mathrm{R}$, the banker prefers to continue a late project and will attract more funds at date 1 by doing so than if he restructures it. So his desire to continue and his need for funds are not in conflict. But if $R<r<\bar{R}$, the banker may want to continue, but given

\footnotetext{
${ }^{11}$ The reader might wonder whether the banker's liabilities might vary with his decision to continue funding the project or not. Given that the bank is solvent, the value of the outstanding deposits will not vary with the decision. Furthermore, the value of capital will depend on the actions that maximize capital's
} 
the interest rate, he will raise more funds per project by restructuring. At this interest rate, his desire to continue is in conflict with his need to raise funds to pay off date-1 liabilities.

Intuitively, the banker sees a date-2 rent from continuation that cannot be pledged to investors at date 1 . As a result, he values continuation more, at least over an intermediate range of interest rates, than do outside claimants. Finally, if $r \geq \bar{R}$, the banker is best off restructuring.

\subsection{An Example}

To motivate what follows, let us see what can happen in equilibrium with an example of how bank failure can be contagious.

Example: Let there be two possible types of banks at date 1: $\mathrm{L}$ and $\mathrm{H}$ where distinguished by the fraction of early projects which is either $\alpha^{\mathrm{L}}=0.4$ or $\alpha^{\mathrm{H}}=0.6$. In the realized state, let fraction 0.6 of banks be of type $\mathrm{L}$ and 0.4 of banks of type $\mathrm{H}$. Let $c_{1}=0.4, c_{2}=0.5, C=1.6, \gamma=0.8, k=0.3$. Plugging in values into (1.4) and (1.5), $\bar{R}=1.95$ and $\mathrm{R}=1.21$. Let the level of outstanding deposits per unit loaned at date 0 be $\mathrm{d}_{0}=1$. When discussing aggregates, we normalize the total amount of loans in the system to one.

Below $\mathrm{r}=1.21$, no solvent bank restructures any projects (because it could always bid a higher rate and save projects as well as enhance its value) so $\mu=0$. Substituting values into (1.2), we find that both types of banks would indeed be solvent. However, the aggregate supply of liquidity is only $0.6 *\left[\alpha^{L} C\right]+0.4 *\left[\alpha^{H} C\right]=0.768$ which is insufficient to deposits and capital. Faced with an aggregate excess demand for liquidity, banks will bid up rates. No bank will restructure to increase supply for any interest rate below 1.21 , hence supply will remain fixed (see Figure 3). But higher rates will reduce demand because it reduces the value of the bank's assets, and thus the value holders of bank capital get.

value, and not on the actions actually taken by the banker. So in choosing between actions, the banker does not have to consider their effect on the outstanding claims. 
When $r>R=1.21$, banks can raise more at date 1 if they restructure late projects. But even though there is an aggregate shortage of liquidity, they have little private incentive to restructure for $\mathrm{r}<\bar{R}=1.95$ unless they have to do so to meet deposit claims. This is because the banker will lose his rents if he restructures.

If the interest rates were just above 1.21, the $\mathrm{H}$ type banks would be able to raise enough to pay depositors and capital without restructuring. But the L type banks have to restructure. In fact, at $r=1.211$, the $L$ type banks cannot raise leven if they were to restructure all late projects. Since there is an aggregate shortage even when they restructure all late projects, the interest rate has to climb above 1.211, and L type banks will become insolvent. Anticipating this, depositors of L type banks will run at date $1 / 2$.

How does the failure of the L type banks change the aggregate excess demand for liquidity? On the one hand, the demand for liquidity falls because depositors in the failed banks have to settle for $c_{1}+\frac{c_{2}}{r}=0.81$ instead of the 1 they are owed, and capital gets nothing. Thus bank failure reduces demand by $0.19 .{ }^{12}$ Of course, since a failed bank restructured all its late projects in an attempt to avoid failure, failure in and of itself does not increase the supply of liquidity. In fact, it reduces the supply of liquidity because early projects are restructured, reducing the supply of liquidity from $\alpha^{L} C=0.64$ to $\alpha^{L} c_{1}=0.16$ per bank. Thus the failure of an $L$ type bank reduces supply by 0.48 per project, which means that the failure of the L type banks increases the aggregate excess demand by $0.6 *(0.48-0.19)=0.17$.

In other words, the failure of the L type banks has a spillover effect in that it increases the aggregate excess demand for liquidity. Seen in another way, the depositors of the failed bank absorb all of the liquidity produced by their bank plus some more when they sell the date- 2 claims on their restructured projects at a price $\frac{c_{2}}{r}$. The net supply of liquidity (at $\mathrm{r}=1.22$ ) 
available to surviving $\mathrm{H}$ banks in aggregate is then $0.4 *\left[\alpha^{H} C\right]-0.6 \frac{c_{2}}{r}=0.116$, not enough to pay their deposits (which aggregate to $40 \%$ of the total, or 0.4 ). Thus the interest rate will have to rise so that $\mathrm{H}$ banks start restructuring projects. At $\mathrm{r}=1.95$, the $\mathrm{H}$ banks are willing to restructure their late projects. Even so, the aggregate supply of liquidity available to surviving banks if they restructure them all is (at $r=1.95)$ :

$0.4 *\left[\alpha^{H} C+\left(1-\alpha^{H}\right) c_{1}\right]-0.6 * \frac{c_{2}}{r}=0.448-0.6 * \frac{c_{2}}{r}=0.294$. As a result, even after the type $\mathrm{H}$ banks liquidate all their late projects, there is still insufficient liquidity for them to repay their deposits of 0.4. Eventually, as the interest rate climbs still higher to 2.77, even type $\mathrm{H}$ banks also fail before demand falls enough to meet supply. Thus all banks fail, and depositors all consume $c_{1}=0.4$, while bankers and entrepreneurs consume zero.

In this example, the total aggregate liquidity that could be generated by the banks if all late projects are restructured (but no banks are run) is $0.6 *\left[\alpha^{L} C+\left(1-\alpha^{L}\right) c_{1}\right]+0.4 *\left[\alpha^{H} C+\left(1-\alpha^{H}\right) c_{1}\right]=0.976$. It turns out that even when outstanding deposits are just 0.976 rather than 1 -- so that there is enough potential aggregate liquidity for both banks to survive -- the only equilibrium is still that both banks fail. Why this is so even though there is sufficient aggregate liquidity to meet demand is worth re-emphasizing. The private incentive of each bank is to free-ride on publicly available liquidity until the price of liquidity becomes high enough $(=\bar{R})$ to make it worthwhile to supply some by restructuring late projects. But before that price, some banks will fail. Bank failures then subtract liquidity from the system, ensuring that when the price is reached, there is too little liquidity for the remaining banks to survive. If instead of many small type $\mathrm{H}$ banks, there was instead a single large type $\mathrm{H}$ bank, its capital owners and bankers would be willing to lend at a subsidized rate to the type L banks, to prevent their joint demise. But with many H type banks, self-interest can overcome collective interest and cause a bank meltdown. Let us now explore all this more systematically.

${ }^{12}$ At the point of failure, capital gets nothing. 


\subsection{What Fraction of Late Projects Will Banks Restructure?}

As we have seen, the prevailing interest rate determines a bank's preferences between restructuring and continuation. But whether a bank has the luxury of following its preferences depends on whether it can do so and still meet the required payments to claimants at date 1 . We have

Lemma 1: (i) When $1 \leq \mathrm{r}<\mathrm{R}$, no solvent bank restructures late projects. Further, let $i^{*}(r)$ be such that $v\left(\alpha^{i^{*}}, 0, r\right)=d_{0}$. Then banks with $i \geq i^{*}(r)$ are solvent, while those with $i<i^{*}(r)$ are insolvent and will be run. (ii) When $R<r<\bar{R}$, solvent bank $i$ will restructure a fraction of late projects which is the minimum non-negative $\mu^{\mathrm{i}}$ such that $v\left(\alpha^{i}, \mu^{i}, r\right) \geq \frac{v\left(\alpha^{i}, 1, r\right)+d_{0}}{2}$. A bank is solvent if $i \geq i^{*}(r)$ where $i^{*}(r)$ is such that $v\left(\alpha^{i^{*}}, 1, r\right)=d_{0}$. (iii) When $r \geq \bar{R}$, solvent bank $i$ will restructure all its late projects. A bank is solvent if $i \geq i^{*}(r)$ where $i^{*}(r)$ is such that $v\left(\alpha^{i^{*}}, 1, r\right)=d_{0}$.

Proof: See Appendix.

Ceteris paribus, the higher the prevailing interest rate the more attractive it becomes for a bank to restructure its late projects. What is interesting is that even if early projects in run banks are being restructured to produce liquidity inefficiently, not all banks have the incentive to restructure late projects and add to the available supply of liquidity. The reason is that because the run bank is insolvent, the interest rate does not reflect the value of liquidity to the banking system. In fact, if $r<R$, Lemma 1 (i) indicates any solvent bank continues all late projects, regardless of whether other banks are being run. The intuition is simple. The banker attracts the maximum funds at date 1 by continuing all late projects. He also maximizes his take by doing so. Therefore, if he cannot attract enough funding to continue all late projects, he has the incentive to 
bid the rate up a little higher so as to attract more funding rather than restructuring late projects. Let us now determine the equilibrium interest rate.

\subsection{The Equilibrium Interest Rate}

The liquidity supplied by a solvent bank $i$ 's projects is

$$
l\left(\alpha^{i}, \mu^{i}\right)=\alpha^{i} C+\mu^{i}\left(1-\alpha^{i}\right) c_{1}
$$

while the liquidity supplied by an insolvent bank is $c_{1}$. Now consider the excess demand for liquidity when $1 \leq \mathrm{r}<\mathrm{R}$ so that the solvent bank continues all late projects. It is

$$
E D_{r<R}=\int_{\underline{i}}^{i(r)}\left\{\left[c_{1}+\frac{c_{2}}{r}\right]-c_{1}\right\} f(i) d i+\int_{i(r)}^{\bar{i}}\left\{1 / 2\left[\alpha^{i} \gamma C+\frac{\left(1-\alpha^{i}\right) \gamma C}{(1+k) r}+d_{0}\right]-\alpha^{i} C\right\} f(i) d i
$$

The term in the first set of curly brackets is the excess demand from a bank that is insolvent while the term in the second set is the excess demand from a solvent bank. Note that even though insolvent banks restructure all their loans, they also sell the date- 2 portion of restructured loans for cash. On net, therefore, they subtract liquidity of $c_{2} / r$ from the overall pool. Differentiating the excess demand with respect to $r$, we get

$$
\frac{d E D_{r<R}}{d r}=-\int_{\underline{i}}^{i(r)} \frac{c_{2}}{r^{2}} f(i) d i-\int_{i(n)}^{T} \frac{1}{2} \frac{\left(1-\alpha^{\prime}\right) \gamma C}{(1+k) r^{2}} f(i) d i+\frac{d i^{*}}{d r} f\left(i^{*}\right)\left[\frac{c_{2}}{r}-\left[\frac{\left(1-\alpha^{i}\right) \gamma C}{(1+k) r}-\alpha^{i}(1-\gamma) C\right]\right]
$$

A higher interest rate will reduce demand because depositors in failed banks will just get the bank's asset value, and this (in particular, the date- 2 portion of restructured loans) will fall with the interest rate. Hence the first term in (1.8). While depositors in solvent banks will get an amount that is invariant in the interest rate, the holders of capital in solvent banks will be paid less because bank asset values (in particular, the value of continued loans) will fall with the interest rate. So demand falls for this reason also, hence the second term in (1.8). 
The third term is particularly interesting. An increase in interest rate causes more banks to become insolvent and run. Whether this increases or decreases excess demand depends on the sign of the term in square brackets. It is the difference between the excess demand of an insolvent bank $\left(=c_{2} / r\right)$ and the excess demand of a bank that is just solvent $\frac{\left(1-\alpha^{i^{*}}\right) \gamma C}{(1+k) r}-\alpha^{i}(1-\gamma) C$ (the first term in this last expression is the liquidity the solvent bank absorbs from the system by continuing late loans, and the second term is the liquidity it indirectly generates for the system by creating early entrepreneurs with spare cash). If by becoming insolvent, a bank's excess demand falls, then we know the overall excess demand for liquidity will fall in the interest rate. This is likely to be true if the bank has few early projects ( $\alpha$ low) so that it does not produce much liquidity while solvent but instead consumes a lot to keep late projects afloat. Such a bank may even release liquidity on net in the process of being run because it will be forced to restructure its many late projects (in addition to the few early ones). So at interest rates where the marginal insolvent bank has low $\alpha$, the excess demand for liquidity is likely to fall in the interest rate.

But a bank could well increase its contribution to excess demand when it fails. For example, when $r>R$, the marginal solvent bank already liquidates all late projects, so failure does not create any additional liquidity. Rather, because early projects are restructured before they produce liquidity, bank failure reduces rather than increases liquidity. ${ }^{13}$

When a bank's failure increases the bank's excess demand for liquidity, it is possible for the aggregate excess demand to increase with interest rates over a range (All that is required is that the increase in excess demand from the mass of additional failing banks outweigh the

\footnotetext{
${ }^{13}$ All the bank's late projects are restructured. So the bank's projects spew out $\alpha^{i} C+\left(1-\alpha^{i}\right) c_{1}$ of cash at date 1 if the bank stays solvent (note that $\alpha^{i}(1-\gamma) C$ of this stays with early entrepreneur). Since the bank is just solvent, all the date-1 amount it can raise, $\alpha^{i} \gamma C+\left(1-\alpha^{i}\right)\left[c_{1}+c_{2} / r\right]$ just meets what it owes date-1 claimants. So the net amount of liquidity the bank releases to the system when solvent is $\alpha^{i}(1-\gamma) C-\left(1-\alpha^{i}\right) c_{2} / r$.By contrast, the net amount of liquidity released when a bank restructures all projects is $c_{1}-\left(c_{1}+c_{2} / r\right)=-\frac{c_{2}}{r} / r$ which is clearly lower. So a bank failure absorbs more liquidity from the system relative to a solvent bank.
} 
reduction in excess demand as a result of higher rates).

Why do we care about the response of excess demand to interest rates? If excess demand decreases in interest rates, then a small rise in interest rates will bring about equilibrium. If, however, it increases, bank runs are destabilizing, and an initial shortage of liquidity could result in a meltdown of the entire banking system as in the example, or a substantial part of it. This accounts for our interest.

\section{Lemma 2:}

(i) $\frac{d^{2} E D}{d r d \gamma}<0$

(ii) $\frac{d E D}{d r}<0$ if $\gamma=1$ and $\mathrm{c}_{2}=0$

Proof: Differentiating the excess demand functions over all the ranges.

The parameter $\gamma$ defines the split between the returns from a project that accrue to the entrepreneur and those that accrue to the bank. Consider an increase in $\gamma$. Ceteris paribus, this increases the bank's receipts. The date-1 receipts to the marginally solvent bank are fully paid out to its depositors. So the higher $\gamma$ does not increase the bank's contribution to the liquidity of other banks. But less is left for early entrepreneurs to inject back into the system, so a bank failure, which leads to the restructuring of early projects, destroys less liquidity. Moreover, the higher returns that accrue at date 2 to the bank from late projects increases the amount of liquidity the solvent bank absorbs at date 1 by continuing them. So a higher $\gamma$ implies that bank failures will release more liquidity, and tend to reduce excess demand as in Lemma 2 (i).

Typically, one would think that countries with better legal and monitoring institutions have higher $\gamma$. This suggests that countries with developed institutions would tend to have selfarresting banking crises, where the failure of a few banks liberates enough liquidity for the rest. 
By contrast, countries with underdeveloped institutions are, ceteris paribus, more likely to have excess demand increasing in the interest rate, which can lead to contagion.

Now consider the intuition behind Lemma 1 (ii). Excess demand increases with interest rates only because a failed bank absorbs more liquidity than a solvent bank. The two sources through which the failed bank reduces what is left for other banks are, first, early entrepreneurs are restructured leaving them nothing to reinvest and, second, the failed bank absorbs more liquidity than it produces when it sells the date- 2 portion of restructured loans. The first effect is zero when $\gamma=1$ (so that early entrepreneurs contribute no liquidity outside their repayment to their bank) and the second effect is zero when $\mathrm{c}_{2}=0$. Hence when there are no spillover effects from a bank's failure, we obtain Lemma 1 (ii).

The equilibrium rate is easiest to characterize when the excess demand for liquidity is monotonically decreasing in the interest rate. Then

Proposition 1: There is a unique equilibrium interest rate. It is

(i) $r=1$ if

$\int_{\underline{i}}^{i(1)} c_{1} f(i) d i+\int_{i(1)}^{\bar{i}} l\left(\alpha^{i}, 0\right) f(i) d i \geq \int_{\underline{i}}^{i(1)}\left[c_{1}+c_{2}\right] f(i) d i+\int_{i(1)}^{\bar{i}} 1 / 2\left[v\left(\alpha^{i}, 0,1\right)+d_{0}\right] f(i) d i$

(ii) $\mathrm{r}$ greater than1 and less than $\mathrm{R}$ if (1.9) does not hold but

$\int_{\underline{i}}^{i^{i}(R)} c_{1} f(i) d i+\int_{i(R)}^{\bar{i}} l\left(\alpha^{i}, 0\right) f(i) d i \geq \int_{\underline{i}}^{i^{i}(R)}\left[c_{1}+\frac{c_{2}}{R}\right] f(i) d i+\int_{i(R)}^{\bar{i}} 1 / 2\left[v\left(\alpha^{i}, 0, R\right)+d_{0}\right] f(i) d i$

(iii) $\mathrm{r}$ greater than or equal to $\mathrm{R}$ and less than $\bar{R}$ if (1.9) and (1.10) do not hold but

$$
\int_{i}^{i(\bar{R})} c_{1} f(i) d i+\int_{i(\bar{R})}^{\bar{T}} l\left(\alpha^{i}, \mu^{i}\right) f(i) d i>\int_{i}^{i(\bar{R})}\left[c_{1}+\frac{c_{2}}{\bar{R}}\right] f(i) d i+\int_{i(\bar{R})}^{\bar{T}} 1 / 2\left[v\left(\alpha^{i}, 1, \bar{R}\right)+d_{0}\right] f(i) d i
$$


(iv) $\mathrm{r} \geq \bar{R}$ otherwise where $\mathrm{r}$ solves

$$
\int_{i}^{i(r)} c_{1} f(i) d i+\int_{i(r)}^{\bar{\tau}} l\left(\alpha^{i}, 1\right) f(i) d i=\int_{i}^{i(r)}\left[c_{1}+\frac{c_{2}}{r}\right] f(i) d i+\int_{i(r)}^{\bar{T}} 1 / 2\left[v\left(\alpha^{i}, 1, r\right)+d_{0}\right] f(i) d i
$$

\section{Proof: Omitted.}

When the excess demand falls in the interest rate, banking crisis can be self-arresting in that the system equilibrates after the required fraction of banks fail. Consider now the other extreme case where beyond a certain interest rate, a bank failure has a negative spillover effect on aggregate liquidity so that the excess demand increase with interest rates. Let $i$ ' be such that $\alpha^{i^{\prime}} \gamma C+\left(1-\alpha^{i^{\prime}}\right) c_{1}=d_{0}$. So banks with $i \geq i^{\prime}$ are self-sufficient in liquidity and will never fail. Further, let $\hat{r}$ be the inflexion point so that the excess demand for liquidity decreases monotonically for $\mathrm{r}<\hat{r}$ and the excess demand increases monotonically with the interest rate for $\mathrm{r}>\hat{r}$ until the interest rate is $\tilde{r}$ and the marginal solvent bank is $i^{\prime}$ (after this, no more banks fail, and the excess demand for liquidity has to fall with increases in the interest rate).

Lemma 3: (i) If there is some $\mathrm{r}^{*} \leq \hat{r}$ such that either (1.9), (1.10), (1.11), or (1.12) hold, then one equilibrium interest rate is $r^{*}$. If there is an excess supply of liquidity at $\tilde{r}$, then $r^{*}$ is the unique equilibrium interest rate. If there is an excess demand for liquidity at $\hat{r}$, then there are two more equilibrium interest rates, one between $\hat{r}$ and $\tilde{r}$, and the other above $\tilde{r}$.

(ii) If there is no equilibrium rate $\mathrm{r}^{*}$ that is less than $\hat{r}$, then the unique equilibrium interest rate is above $\tilde{r}$, and all banks that are not self sufficient in liquidity fail. If there are no self-sufficient banks, the banking system melts down completely, and the interest rate is infinity.

\section{Proof: Omitted.}

It is possible that the system equilibrate at a low interest rate. Even so, multiple equilibria are possible, one of which involves runs on all banks that are not self-sufficient. The equilibrium with only self-sufficient banks surviving is a self-confirming flight to quality. All expect that 
only the self-sufficient banks will survive, and that non-cash asset values (the date 2 portion of restructured assets) will be highly discounted, offering very high rates of return to those who use their spare cash to buy them. These high rates of return will be above those that non-selfsufficient banks can offer. Since the self-sufficient banks do not need new deposits, only they will survive given these beliefs, and the rate of return from buying during the fire sale will indeed be very high. These equilibria are Pareto ranked so any intervention that helps the system select the lowest equilibrium interest rate is desirable. It is also possible that the unique equilibrium that can exist is one with runs on all banks except the self-sufficient ones. In this case, more drastic intervention may be needed (see next section).

Depending on the distribution of banks, it is possible to get a variety of ways in which the excess demand for liquidity can vary with the interest rate. We do not have the space here to discuss all configurations, but we have given the reader a sense of the kinds of equilibria possible.

\subsection{Discussion.}

\subsubsection{The Consequences of an Aggregate Liquidity Shortage}

A shortage of date-1 consumption goods (liquidity) arises in this model because depositors have non-negotiable claims against banks and a strong preference for date-1 consumption. The production of liquidity in the natural course may be insufficient to meet the pre-contracted demand. Equilibrium is restored by three processes. First, negotiable claims for liquidity against banks (i.e., capital) are eroded away by a higher interest rate. Second, the nonnegotiable claims of deposits are eroded through bank runs (which are triggered by higher rates). Third, higher rates provide banks more incentive to produce liquidity by restructuring projects.

Bank runs, however, create two kinds of problems. A run destroys banks, and hence their ability to extract more from borrowers. Since the bank's "collateral value", which is normally passed through to its depositors, is extinguished, it can no longer perform its role of drawing consumption goods from potential depositors at date 1 (early entrepreneurs who would deposit based on the value of bank loans to late projects) and passing them on to depositors. Thus, after a 
run, early entrepreneurs may have spare liquidity that they cannot pass on to depositors because the latter have no purchasing power. Liquidity is "trapped" in the wrong place.

Note that this kind of allocational problem would occur even if banks did not liquidate early projects during the course of a run. It occurs because the bank's institutional structure is a mechanism for putting the banker's skills at the service of depositors. The bank thus establishes property rights (for date-1 claimants) and facilitates trade (between early entrepreneurs with spare cash and date-1 claimants with claims on late projects). A bank run reduces the bank's asset values, eroding the date-1 claimants' property rights, and thus reducing trade.

But a bank run can also destroy value because liquidity is produced very inefficiently. Banks are forced to scramble for liquidity before date 1 because they have issued demandable claims, and not because depositors want to consume. All of the early projects in failing banks are restructured at date $1 / 2$. In fact, depositors collectively would be better off waiting till date 1 , because they could allow early projects to mature. Instead, they will be forced to join the run if there is a severe anticipated liquidity shortfall, thus forcing an unnecessary demand for liquidity, which, in turn, will force the bank to restructure inefficiently. In this way, the capital structure of banks, which we argue offers investors an expectation of greater consumption goods in times when there is adequate aggregate liquidity (by giving depositors a cast iron demandable claim to a consumption good even if there are only illiquid long dated assets backing it), absorbs liquidity when there is an aggregate shortage. Entrepreneurs, capital, and the banker will get nothing, and depositors will get a small fraction of what they are owed, or even of what they could get if their nominal claims were not so large as to make them run.

Finally, even though we do not have a full-fledged dynamic model, there is a sense in which a bank run could be contagious - not because it makes more depositors of hitherto safe banks focus on run equilibria, nor because a run conveys information about the solvency of banks in the region, but because a run subtracts liquidity from the system, which could trigger runs at other banks as well. We have seen these spillovers could lead to multiple interest rate equilibria, with a relatively healthy scenario for the banking system possible at the same time as a complete 
meltdown.

The fragility of banks cannot be easily contracted away. Even if the timing of the investors' liquidity demand can be forecast perfectly (in this model all liquidity demand is at date 1), deposits have to be demandable at any time to prevent them from being renegotiated down. This necessary fragility of the bank's capital structure, however, leaves it exposed to the arrival of information at an inopportune time.

\subsubsection{Liquidity Shortages and Solvency Problems.}

A prior literature has shown that liquidity shortages could cause solvency problems and bank failures. Since liquidity shortages have been thought of as system wide rather than the actions of any particular banks, some have concluded that intervention is warranted to ward it off (see, for example, Bagehot (1873)). By contrast, it has been felt that insolvency arises more from the actions of individual banks, and is also less likely to have systemic consequences. Hence, there has been very little support for interventions that directly help banks avert insolvency.

These perceived differences between liquidity problems and solvency problems may, according to our model, be overstated. Solvency problems at particular banks may create liquidity shortages that then make the whole system insolvent. In other words, the line of causality is not only from illiquidity to insolvency, it could be reversed. Moreover, because of these links, it may be hard to tell whether the root cause of a banking crisis is insolvency or illiquidity.

In particular, suppose all banks could meet their liabilities if the interest rate were 1. However, because liquidity is short, the equilibrium interest rate is higher than 1 , rendering a number of banks insolvent. Banks are insolvent at current market rates, but the root cause is too little liquidity. This is hard to tell apart from an observationally close outcome, but with a different root cause: Suppose now that some banks are insolvent at an interest rate of 1. Further, suppose that they consume liquidity while failing, creating a shortage of liquidity. This will push 
up interest rates and bring down more banks. In equilibrium again, some banks will be insolvent at current market rates, but the root cause now is the insolvency of a few banks.

Perhaps, one could argue, the difference between solvency problems and liquidity problems has to do with the method of resolution. Liquidity problems are resolved by infusing liquidity. One might argue this involves no taxes, and no alteration of property rights. Solvency problems, on the other hand, are resolved through taxes and transfers, and this does require altering property rights in the economy. From the libertarian's perspective, the former is much more preferable to the latter (see e.g., Thornton or Bagehot). These characterizations, our model suggests, are too extreme. Both liquidity problems and solvency problems, as we will shortly argue, are resolved in an economy by altering property rights. All that is different between these forms of interventions is the identity of who is expropriated.

If the precise nature of the problem is so difficult to distinguish, perhaps it does not matter (other than to libertarians) what kind of problem regulatory authorities think it is while intervening. Again this is incorrect. Misdiagnosing a liquidity problem as a solvency problem, and intervening on that basis, could make the banking system much worse. We will explore all this shortly.

\subsubsection{Related Literature.}

Our work is related to a number of important recent papers. In particular, while Caballero and Krishnamurthy $(1999,2000)$ and Holmstrom and Tirole $(1997,1998,2000)$, also focus on crises, the notion that banks create liquidity for depositors is less central to their argument. Moreover, by liquidity they typically mean collateral value or wealth, while we introduce an additional notion of immediacy in this paper. The notion of loans as being illiquid due to the lender's specific lending skills, as well as his inability to commit, is in our earlier work (Diamond and Rajan (2001a)) as well as in Kiyotaki and Moore (2000). Kiyotaki and Moore do not focus on the structure of bank contracts or on banking crises. While in Diamond and Rajan (2001a), we examined bank deposit structures as commitment devices, we focused only on solvency issues 
(by assuming that storage was always in use, implying there existed a sufficient supply of aggregate liquidity at the rate of return on storage).

Our paper also relates to Allen and Gale (2000), Bhattacharya and Gale (1987), Diamond (1997), Diamond and Dybvig (1983), Donaldson (1992, 1993), and Smith (1991), in its focus on the consequences of an aggregate shortage of liquidity. But there are three important differences between our paper and much of this literature. First, the sequential service constraint inherent in demand deposits, which is the source of bank runs and systemic fragility, is not superimposed in our framework but is necessary for the function the banks perform.

Second, we examine liquidity shortages stemming from the bank's asset side -- from exogenous delays in the generation of project cash flows by borrowers or endogenous shortages stemming from the early termination of projects. Most of these earlier studies view liquidity shortages as stemming from the bank's liability side -- from endogenous panics or exogenous fluctuations in the liquidity demanded by depositors. The difference is important. Individual bank runs in those models lead, at best, to fire sales of long term assets and, at worst, to the premature liquidation of long term assets if these assets are assumed to be non-transferable (as, for example, in Allen and Gale (2000)). But runs then do not exacerbate shortages since the run bank liquidates assets to pay off depositors. In fact, if the bank liquidates long-term assets to pay off depositors who do not need to consume, then a run can alleviate shortages since these depositors can redeposit in sound banks (a flight to quality). Thus if there is no aggregate liquidity shortage to begin with in these models, the mere fact that some banks become insolvent and are run cannot create a shortage. In our framework, by contrast, this is a very real possibility. An aggregate liquidity shortage (and possible contagion) can be caused by bank runs precipitated by bank insolvency, even if there is no shortage in the absence of the runs. The difficulty of telling apart aggregate shortages caused by the intrinsic shortage of the liquid asset and aggregate shortages caused by bank insolvency is a key point of our paper.

The third difference stems from how contagion arises. In Diamond-Dybvig [1983] and multi-bank developments of the framework (see Bhattacharya and Gale (1987), Smith (1991), or 
Allen and Gale (2000)), banks have to fail when the aggregate demand for liquidity exceeds the supply of liquid assets. In particular, Smith (1991) presents a model with fluctuations in both aggregate demand and individual local bank demand for liquidity. Just as individual uncertainty leads depositors to pool in a bank in Diamond-Dybvig [1983], these banks will pool their investments in a bankers' bank. However, when the realized demand of all depositors exceeds the supply, then the banker's bank will fail, and as a result many of the individual banks will be forced to fail as well. Allen and Gale (2000) present a related model where there are inter-bank cross deposits, instead of a bankers' bank. Again, when the sum of the liquidity demands at cross deposit-linked banks exceeds the combined supply, linked banks have to fail. ${ }^{14}$ In our paper, however, bank runs can lead to a severe contraction in the supply of liquidity. This then becomes a source of contagion, which is present even if there are no explicit links between banks ex ante (unlike, for example, in Smith (1991) or Allen and Gale (2000)). Liquidity contraction as a result of runs also becomes a source of multiple real interest rate equilibria. Since these phenomena underlie rationales for intervention, the difference in our approach is not inconsequential.

\subsection{The Date-0 Decision: Lending vs Storage}

Thus far, we have ignored the storage decision. Since banks have the option of storing, and can finance storage entirely with deposits (they do not have to hold capital against storage), would they optimally store so as to avoid runs? It turns out that

Proposition 2: In equilibrium, banks will either store all the funds they raise or store nothing.

Proof: See Appendix.

The intuition stems from the fact that the bank determines both its level of deposits and the extent of storage simultaneously at date 0 . Competition forces it to maximize the amount it

\footnotetext{
${ }^{14}$ Prices of assets are driven in our model by the aggregate excess demand for liquidity, which is affected by bank failure. This resembles Diamond [1997], who studies a model where not all investors are always active in secondary markets and where a secondary market for long-term assets exists. Investors will hold assets, especially short-term assets, through banks, and if banks fail, the secondary market price of long-term assets will fall because liquidity can end up in the wrong hands (those who do not need to consume, but do not participate in secondary markets).
} 
can pledge to pay at date 1 to date- 0 investors. The amount that it can pledge depends on both what its assets generate and what its liabilities force it to pay out. One might think that the bank might want to avoid a destructive default by storing an additional unit of consumption good at date-0 instead of lending it, so that it is available if the bank's $\alpha$ turns out to be low. But an equivalent action is to reduce the level of outstanding deposits by one unit, and instead raising the balance with capital. And if lending generates more pledgeable value than storage, the bank will prefer the latter action and store nothing. By contrast, if storage generates more pledgeable value, the bank will prefer to store everything. ${ }^{15}$

That banks will not store when they lend suggests that our analysis thus far, where we assumed storage by the banks was zero, is not irrelevant. ${ }^{16}$ We have, however, examined aggregate states where the equilibrium is a meltdown of the banking sector. If that were the only aggregate state anticipated at date 0 , it is clear that banks would not lever to the extent that would cause a complete meltdown. They would either issue fewer deposits, or not lend at all. But if the aggregate state where a meltdown occurs is a low probability event, and banks determine their deposit levels keeping in mind a less unfavorable, higher probability, aggregate state, then melt downs will be observed in the eventuality that the unfavorable state is realized.

Finally, we do not analyze the way the level of deposits, $d_{0}$, is optimally set here. This exante problem is a constrained maximization problem that offers insights largely peripheral to the focus in this paper, which is on what happens if in the realized state the level of deposits exceeds available liquidity. We also do not allow for deposits to be made contingent on the interest rate or the non-verifiable information about the state of nature. Given that the distribution of bank types varies across states, it is easy construct a number of states in which the same interest rate prevails

\footnotetext{
${ }^{15}$ Clearly, with some scale effects in the returns to storage or lending, we would get an interior solution. But what we can show is that even though bank runs make the returns to lending non-linear in the realizations of $\alpha$, the pledgeable value is not non-linear in the fraction lent, which is all that is important for the date- 0 decision.
} 
but the optimal level of deposits is quite different. Given that there is no one-to-one mapping between the state and the interest rate, and given that banks compete to pay out the maximum possible, we can provide examples where the ex ante equilibrium interest rate contingent deposit structure creates liquidity or solvency problems for some banks in some states, and may even result in (low ex-ante probability) states with a complete meltdown of the banking system. Our analysis is positive - what happens when there is an ex-post solvency or aggregate liquidity shortage given use of demand deposit contracts. Obviously, if there were no uncertainty about the ex-post state of nature, or if there were complete markets, no such conditions would arise.

\section{Intervention at date 1}

Banks fail whenever depositors anticipate losses. The consequent loan restructuring can hurt depositors and borrowers ex-post, and may possibly cause other banks to fail if an excess demand for liquidity is created or exacerbated. As a result of the possible ex-post problems, a government or central bank with the ability to influence interest rates or the survival of particular banks may find it attractive to intervene. Even if we ignore the effects of interventions on the ex ante incentives of the banks (or potential ex post bargaining between the bank and the intervening authority), it is by no means clear that intervention is appropriate, or will have the intended effect. The proximate cause of a run is that a bank is deemed unable at current interest rates to raise enough to pay off depositors - it is insolvent. But insolvency can both cause, and be caused by, liquidity problems. As a result, the effects of interventions that attempt to address either the insolvency of particular banks or the liquidity of the banking system need to be evaluated considering the full general equilibrium. The sometimes-contagious effects of bank failures suggest that interventions may have surprising or unintended effects. One must understand the "technology" of various feasible government interventions before reaching any conclusions on

\footnotetext{
${ }^{16}$ From the perspective of the banking system, storage by individuals factors out since individuals consume all that they store.
} 
their desirability. We show that some interventions are ineffective and others are counterproductive even ex-post.

\subsection{The Forms of Intervention.}

Since there are no spare resources held outside the system, any intervention will necessarily require taxing some group and transferring to another. Let us consider the forms of intervention. We will not allow the intervening authority (henceforth called "the central bank") to have any special power of extraction. In particular, the central bank can tax resources that are already invested in the banking system (for example, existing depositors) but cannot force entrepreneurs to produce or to abstain from consumption. So once entrepreneurs have money left over after repaying loans, the central bank has to make it worthwhile for them to redeposit it in the system by committing to tax only a portion.

The central authority can increase the current (e.g, date 1) supply of external funds to the financial system or to particular banks by taxing current goods to fund loans at an interest rate lower than the taxpayer would choose to lend voluntarily. If such a loan is at the market rate of interest that prevails given the loan, we define the tax and transfer operation as a pure liquidity

infusion. A pure liquidity infusion increases the supply of funds at a given interest rate. The role of a liquidity infusion is to prevent bank failures by warding off a rise in interest rates due to an excess demand for liquidity. If instead the central authority uses its taxation power to provide a particular bank a gift of future value, for example a claim on date 2 goods, we define the tax and transfer operation as pure capital infusion. The role of a capital infusion is to allow a recapitalized bank to survive at a given or higher interest rate, to avoid the effects of its failure on the bank and on other banks. All financial market interventions can be viewed as some combination of pure liquidity and capital infusions. For example a gift of current goods to a bank is a liquidity infusion equal to the quantity of current goods, plus a capital infusion equal to the date-2 value of those goods, evaluated at the market interest rate that prevails given the gift. It will have different general equilibrium effects that a pure liquidity or capital infusion. 


\section{Liquidity infusion}

The way to infuse liquidity into the banking system is to tax date- 1 consumers and lend to banks on terms that the consumers would not choose to offer. In principle, any date-1 holdings of consumption goods can be taxed, but since early entrepreneurs and cash-rich banks already infuse all their consumption goods into the system (provided there is no solvency problem), the taxes have to fall on depositors or capital. Taxing the date- 1 claimants after they withdraw consumption goods from the bank will ensure the proper tax is collected without destroying bank incentives to pay depositors. The proceeds of this tax may then be re-deposited in solvent banks at random. All or some of the tax may instead be used to quickly buy the date 2 portion of restructured loans sold by insolvent banks - similar to methods used by the RTC to resolve the Savings and Loan problems of the 1980's in the United States. If the root cause of the banking system's problems is a liquidity shortage, the liquidity infusion will reduce the excess demand for liquidity at date 1 and bring down the interest rate, which will make banks that were insolvent at the prior equilibrium rate solvent again, and eliminate runs.

A pure liquidity infusion does not require particular investors or banks to be targeted. In fact, investors are taxed after they are paid by the bank to ensure the bank does not get a windfall due to a reduction in deposits. Similarly, liquidity is made available at the new equilibrium market interest rate, so that no borrowing bank gets a windfall. But clearly, relative to the equilibrium interest rate that would prevail if there had been no intervention, banks as a whole do get a windfall infusion of value. So liquidity infusions do alter property rights. Late entrepreneurs benefit unambiguously because fewer of their projects are restructured. Early entrepreneurs in banks that would not fail absent the intervention are unambiguously hurt because the interest rate they would get for their surplus funds is lower. Whether a banker is better or worse off depends on whether the realization of early projects in his portfolio made him a net borrower or investor.

Finally, a liquidity infusion (financed by a tax on deposits plus capital) may reduce aftertax payments to deposits and capital across all banks because the reduction of interest rates affects the production of liquidity. Even though liquidity is no longer destroyed by bank runs, it 
may also not be created in the same quantities as it would absent intervention: Banks, once solvent, may not restructure as many late projects as they would have if insolvent, or may restructure fewer projects because of the lower post-intervention interest rate. There are, however, circumstances where date- 0 investors as a group are better off as a result of the intervention. But this still leaves those with surplus funds to invest at date 1 worse off.

\section{Interest rate guidance: Potential liquidity infusion}

We have seen the possibility of multiple real interest rates at which the banking system might find equilibrium. Clearly, one possible form of intervention is for the central bank to coordinate expectations at the lowest equilibrium interest rate. It could do this by being prepared to lend and borrow at that rate. ${ }^{17}$ This transaction is a promised pure liquidity infusion (evaluated at the low equilibrium rate), which need never occur in equilibrium. While the central bank may potentially need significant taxation authority to give it credibility that it will take sufficiently large positions, in equilibrium it will not need to raise resources. Even though no resources are used, unless all banks were to fail absent intervention because of a high interest rate, intervention will not make all better off. Early entrepreneurs in banks that do not fail, and cash-rich banks, are made worse off (because intervention lowers the rate of return earned on their excess date-1 consumption goods).

\section{Capital Infusion}

The government can also provide capital by giving a bank at date 1 claims on date 2 consumption goods. Recapitalizations have to be targeted since they assure the solvency of specific banks. An infusion of capital into one part of the banking system will not spread through the system to help other banks survive (in fact, as we will see, it can cause the reverse). Recapitalization of a given bank prevents it from affecting other banks though its failure. What is

\footnotetext{
${ }^{17}$ If the excess demand is falling with interest rates at the first interest rate equilibrium, then it will be sufficient for the central bank to lend at any rate below the next higher equilibrium interest rate.
} 
important to a given bank's survival (holding equilibrium interest rates constant) is the date 2 value of the gift. ${ }^{18}$

The government can obtain the funds needed for a capital infusion by taxing either date-1 or date- 2 wealth. For instance, it can tax banks that have a high realization of $\alpha^{\mathrm{i}}$ by writing deposit claims against them, and granting the deposit certificates to banks that have borrowers with early projects (a low realization of $\alpha^{\mathrm{i}}$ ). Alternatively, it can offer bonds maturing at date 2 to insolvent banks, with the payment on the bonds being funded by a tax on maturing claims at date 2. Infusions of value funded by taxes on date- 2 consumption are pure capital infusions. A tax can also be imposed on claimants withdrawing on or before date 1, and the proceeds gifted to needy banks. This last intervention is both a liquidity and a capital infusion.

A capital infusion may save particular banks when a liquidity infusion will not. For example, suppose the interest rate is 1 at date 1 , but banks fail because they are insolvent at that rate. If the government wants to save them (to protect their borrowers), a recapitalization will allow them survive and attract liquidity, but an infusion of liquidity into the system will be no help. Since there is already enough liquidity and the interest rate cannot go below 1, additional liquidity will just go waste.

\section{Recapitalization in order to avoid a meltdown}

If the role of intervention is to prevent a systemic problem because bank failures lead to an escalating excess demand for liquidity, the value of recapitalizing a bank depends on its characteristics. Holding interest rates constant, providing just enough capital to all a bank with $\alpha^{i}$ early borrowers to survive when it restructures a fraction $\mu^{i}$ of its late borrowers, decreases the excess demand for liquidity by $\left.\alpha^{i}\left\{\frac{c_{2}}{r}+(1-\gamma) C\right)\right\}-\left(1-\alpha^{i}\right)\left\{\left(1-\mu^{i}\right) \frac{\gamma C}{(1+k) r}+\mu^{i} \frac{c_{2}}{r}\right\}$ times the

\footnotetext{
${ }_{18}^{18}$ If the market value of the banking sector as a whole, when no late projects are restructured, exceeds the aggregate value of deposits, then a transfer of value (such as a forced merger) can be enough to recapitalize the insolvent banks. If that market value is insufficient then value must be transferred from some other source, such as taxing depositors or entrepreneurs, present or future.
} 
mass of banks of type $\alpha^{\mathrm{i}}$, where the value of $\mathrm{r}$ determines the amount of restructuring, $\mu^{i}$, that the bank will choose (as in Lemma 1). Saving banks with low values of $\alpha^{i}$, such as $\alpha^{i}=0$, does not decrease the excess demand for liquidity, and at low interest rates may in fact increase it (because the banks will prefer not to restructure late borrowers and set $\mu^{i}=0$ ). For a sufficiently high $\alpha^{\mathrm{i}}$, saving banks of type $\mathrm{i}$ will decrease the excess demand for liquidity purely by avoiding the liquidity absorbing effects of a run that forces restructuring of its early projects. This implies that recapitalizations are best targeted at banks that will be intrinsically more liquid in the near term than at banks that will be illiquid.

An additional benefit of recapitalization is that it allows high interest rates to prevail without causing the failure of high $\alpha^{\mathrm{i}}$ banks. High interest rates, holding bank failure constant, force a solvent bank to restructure late projects. ${ }^{19}$ A generalized recapitalization of all insolvent banks can allow high interest rates to prevail without bank failures. Liquidity is then produced more efficiently (through the restructuring of late projects rather than through the restructuring of early projects).

We can summarize our discussion as follows:

\section{Proposition 3:}

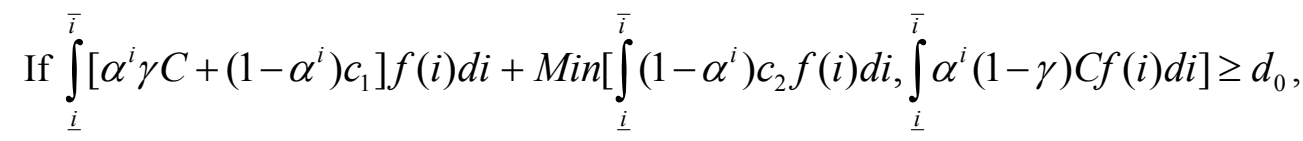
then all banks can be made solvent by an appropriate injection of capital.

(ii) A pure liquidity infusion will save all banks if and only if

$$
\alpha^{i} \gamma C+\left(1-\alpha^{i}\right) \frac{\gamma C}{(1+k)} \geq d_{0} \forall \quad i>\underline{i}
$$

Proof: Omitted.

\footnotetext{
${ }^{19}$ Another way to achieve this objective is to offer to buy loans to late projects on condition that they will be restructured.
} 
Part (i) states that if there is enough liquidity that can be appropriated by the banking system to pay off deposits, then there is some recapitalization scheme that can allow the liquidity to flow to the right places, no matter what the realization of the $\alpha^{\prime}$ 's. Note that the cash left with early entrepreneurs after repaying loans is counted as part of the liquidity that can be appropriated by the banking system only if there is enough date- 2 value to pay it the storage rate of return. ${ }^{20}$ In other words, even though the government has taxation power, we limit the amount of financial repression that it can impose. Part (ii) states that an infusion of liquidity is of no use in saving banks when the problem is purely one of solvency (i.e., banks are insolvent even at an interest rate of one). But if a liquidity shortage causes solvency problems, then a liquidity infusion can save all banks.

\subsection{Can Intervention be Harmful?}

Should the central bank worry about the form of intervention it chooses? It should! First, as the proposition indicates, there may be no feasible capital infusion that will save the system if the problem is a fundamental liquidity shortage. Infusions of capital will then simply push up interest rates, causing a need for more capital infusion, but without clearing the market for liquidity. Similarly, there may be no feasible liquidity infusion that saves all banks if the problem is a fundamental lack of solvency.

Incomplete and misdirected provision of capital can make matters worse. For example, suppose liquidity is tight so that gross interest rates are greater than 1 but less than $\mathrm{R}$ and that low $\alpha$ banks fail in the absence of intervention. Suppose now that the central bank bails out the low $\alpha$ banks by recapitalizing them to the point that they do not fail (e.g., by guaranteeing deposits and exercising forbearance). We showed that saving low $\alpha$ banks that do not restructure late projects (because $r<R$ ) will increase the excess demand for liquidity - they would release liquidity if they failed. Enabling these banks to pay higher interest rates on deposits will be increase market interest rates. Now banks with moderate $\alpha$ may fail. But these banks are more likely to subtract

\footnotetext{
${ }^{20}$ Otherwise, the entrepreneur would store rather than invest in the banking system. In other words, we are assuming that no matter what the prevailing market interest rate, the early entrepreneur's returns on
} 
liquidity from the system when they fail, and their failure will kill more borrowers with early projects. Thus recapitalization of failed banks may destroy many healthier banks. The failure of these banks may be much more harmful for the system, and may lead to a contagion of failures.

Put differently, a small recapitalization of the worst banks may soon trigger the need for a massive recapitalization. If on embarking on this process of potentially cascading recapitalization, the central bank does not have the political clout to carry it out to the end, it may violate perhaps what should be the most important rule governing interventions: First do no harm!

The previous proposition suggests that if there is neither a fundamental liquidity shortage, nor a fundamental lack of solvency at some banks, either a capital infusion or a liquidity infusion can save the banking system. It may still matter which tool is used, if there is a cost of intervention, which increases with the size of intervention. Taxes and transfers create deadweight costs. Sometimes, a small liquidity infusion can save a system, while a massive capital infusion would be needed to achieve the same end, and vice versa. Knowing what the appropriate intervention is can save substantially on deadweight costs. For example, take the case that there are a few banks with low $\alpha^{i}$ and lots of banks with high $\alpha^{i}$. There is too little liquidity in the system so the interest rate is pushed up to the point where the low $\alpha^{\mathrm{i}}$ banks fail. But no extra liquidity will be forthcoming at higher rates until the rate is pushed up to the point that the high $\alpha^{\mathrm{i}}$ banks will deem it worthwhile to restructure late projects. But for the low $\alpha^{\mathrm{i}}$ banks to continue to be solvent at that high rate will require a massive recapitalization. It will be far cheaper to infuse a little additional liquidity to save them.

But our aim here is not so much to suggest a particular form of intervention, as it is to say that interventions can have subtle effects, and their effectiveness depends on the situation. A substantial amount of information is required on the part of regulators, even before one delves into the precise economic effects at work. For example, one cannot simply use the real interest rate to tell apart a solvency problem from a liquidity problem. It may well be that the root cause 
of a high real interest rate is a failing bank which is subtracting liquidity from the system.

Conversely, it may be that the root cause is too little liquidity to start with.

If one were to adopt the principle "First, do no harm!" it would seem from our model that a liquidity infusion is the most benign in terms of its spillover effects. A liquidity infusion cannot trigger off a cascade of bank failures, and it may well arrest one. And a liquidity infusion will, at least, save the most solvent banks, without the central bank having to pick and choose. But as we argue, there are situations when a liquidity infusion may be ineffective. If the central bank has the luxury of time and can sequence intervention, it may make sense to first attempt a liquidity intervention, and then think about a capital infusion. This would have the effect of identifying the banks that really need help. We have, however, not modeled the gaming that would take place anticipating such intervention.

\subsection{Other interventions}

Before we end, let us see how common forms of intervention can be decomposed into liquidity and solvency infusions. We can also see what interventions might work in our example.

Suspension of convertibility is both an injection of liquidity and of capital, financed by the date- 0 investors in a bank. The direct effect of suspension is to eliminate a bank's need to pay out immediately. This will stop runs if suspension continues until all entrepreneurs can repay their loans. Even if suspension continues only until early entrepreneurs generate cash, it will prevent the destruction of liquidity, and possible contagion. If multiple interest rate equilibria were possible in the absence of intervention, suspension will result in an interest rate after suspension is lifted which is at most equal to the lowest equilibrium rate. ${ }^{21}$ However even a temporary suspension will facilitate renegotiation. Depositors will no longer have the ability to run immediately, and will be inclined to reach an efficient bargain with their banker (this also transfer rents and possibly liquidity to the banker). Thus suspension has the effect of both providing sufficient liquidity and capital for each bank to survive, but only because initial

\footnotetext{
${ }^{21}$ The interest rate could be lower than the lowest non-intervention equilibrium rate if some banks were run, destroying liquidity, absent intervention. More liquidity would be available after suspension, leading to possibly a lower rate.
} 
claimants finance it. It will thus reduce their consumption by reducing their bargaining power over the banker.

Deposit insurance is akin to a potentially unlimited infusion of capital, where the actual amount of capital provided depends on the interest rate offered by banks. Deposit insurance allows a bank to survive, regardless of the interest rate it offers. When there exists an interest rate at which the market for liquidity will clear with no banks failing, deposit insurance will prevent bank runs (with late entrepreneurs bearing the brunt of the cost and early entrepreneurs getting the benefit - a form of short-termism). However, when there is excess aggregate demand for liquidity at all interest rates, the banking system will fail immediately despite the insurance. Without an injection of liquidity, interest rates will spike upwards, but any finite injection of capital will not allow the market to clear, and no new deposits will be forthcoming.

\subsection{Interventions in the example.}

Let us now go back to our example to see what interventions can work. In the original equilibrium, all banks fail, depositors each consume 0.4 , and bankers and entrepreneurs consume zero. The example illustrates an aggregate liquidity shortage that forces type L banks to fail, bringing down the banking system. There are interventions that Pareto dominate the outcome.

\section{Pure liquidity infusion.}

A pure liquidity infusion can result in a Pareto superior outcome by increasing the supply available to banks, and thus preventing interest rate from spiking up until all banks fail. A small injection of liquidity can save the type $\mathrm{H}$ banks, by allowing the interest rate to drop below $\mathrm{r}=2.77$ (the level that makes type $\mathrm{H}$ banks insolvent), but it cannot prevent the run on type $\mathrm{L}$ banks, because they are insolvent at any interest rate in excess of $r=1.21$. Aggregate liquidity supply is 0.688 (with $\mathrm{H}$ banks liquidating all late projects), demand is 0.748 (the value of claims on failed type L banks plus just solvent type $\mathrm{H}$ banks), implying that a liquidity infusion of 0.06 will suffice. The government should tax 0.06 from depositors of $\mathrm{H}$ banks after they withdraw, and 
lend it at date 1 to any bank that can repay at an interest rate of $r=2.77$. The government should collect repayment at date 2 , and give it to consumers at that time. Consumers should not be able to borrow at date 1 against the date 2 payments else they will compete with the banks for liquidity (this can be arranged if the payments are as public goods, for example). If there are no dead weight costs of the tax, expected after tax consumption will be 0.688 at date 1 , averaged across all depositors and capital holders.

A large liquidity injection can allow both types of banks to survive, by driving the interest rate down to 1.21 . This large liquidity intervention cannot increase date-1 consumption above 0.768 : $\mathrm{L}$ banks are insolvent when $\mathrm{r}$ exceeds 1.21 and the interest rate has to go to 1.22 for any banks to liquidate late projects. At $\mathrm{r}=1.21$, liquidity demand is 1.0188 (the value of just solvent type $\mathrm{L}$ banks plus more than solvent type $\mathrm{H}$ banks), and the supply is .768, implying that the government must tax 0.2508 in date 1 goods, and lend them out as deposits at $r=1.21$. A capital injection is required to increase date- 1 consumption above 0.768 , because interest rates must reach at least 1.22 to encourage the liquidation of late projects.

\section{Recapitalization}

Because deposits exceed the maximum available liquidity (at any interest rate), there can be no pure capital injection that prevents the meltdown of the banking system. However, capital injections can provide better outcomes when combined with injections of liquidity. If a small recapitalization is combined with a relatively large liquidity injection which allows the type L bank to survive at $r=1.22$ (where $\mathrm{L}$ banks will restructure late projects to survive), then liquidity supply can be increased to 0.912 . At $r=1.22$, liquidity demand is 1.017 (with both types of bank solvent), and the amount taxed from date- 0 investors and relent at market rates must be only 0.105 plus the small cost of recapitalizing the type $\mathrm{L}$ banks to allow them to survive at an interest rate of $\mathrm{r}=1.22$ (a gift of 0.01 times the L banks' deposits of .6 in date 2 goods). In this case, a recapitalization combined with liquidity infusion is much less expensive than just providing liquidity.

Alternatively, a larger capital infusion combined with less liquidity allows type L banks 
to survive when the interest rate rises to $\bar{R}=1.95$, where type $\mathrm{H}$ banks will supply liquidity by restructuring all late projects (calling loans). The type $\mathrm{H}$ banks are solvent at $\mathrm{r}=1.95$, but the type L banks must have additional capital of $(1.95-1.21) * 0.6=0.44$ at date 2 . At 1.95 , liquidity demand is 1.006 (if both types are solvent) and supply is 0.976 , so there must also be a liquidity infusion ( $\operatorname{tax})$ of 0.03 .

We have not compared the costs of intervention, both in terms of whom they impact and how much deadweight cost they entail. One important message from our model is that liquidity interventions are not costless, especially if one considers the general equilibrium. Quantifying such costs is a task for future work.

\section{Conclusions.}

We have examined how liquidity shortages and solvency problems in banks interact, and how each can cause the other. Interestingly, the possibility of a contagion of banking failures arises precisely because of the very structure of banks - they finance illiquid assets with demandable claims. But such a structure is also what helps them provide liquidity. Thus there are no easy ex-ante fixes (such as mandating the matching of liquid assets and liquid liabilities - a proposal that resurfaces under various guises, lately termed "narrow banking") to the problems we describe. The ex-post (i.e., during crisis) interventions are also not clear-cut: Liquidity support is not as benign as some have made it out to be, nor is an infusion of capital into select banks without any redeeming purpose. All one can say without knowing the precise parameters of the situation is that the provision of liquidity support is unlikely to make matters worse for the banking system. The same cannot be said for recapitalization (see Diamond and Rajan (2002) for an example based on this model).

It is important to note that this model implies that the contagion of bank failures need not be based on panic unrelated to fundamentals of the economy (which occurs here only in the choice between one of several equilibria when such exist). Because bank failures themselves can cause liquidity problems, our analysis suggests that evidence that bank failures can be predicted 
with economy wide business conditions is not sufficient to indicate that such failures are benign (as suggested by Calomiris and Gorton (1991) for example). Just because they are not "pure panics" (i.e, sunspots) does not mean that the bank runs are in the collective interest of depositors in run banks or that they do not have large external effects. In addition, the spillover works through local deposits and firms. This suggests the possibility of local contagion as well as the possibility of national contagion. Finally, if runs are not instantaneous (for example, if the state of nature is learned sequentially by different depositors), then real effects of a bank calling loans (forcing the restructuring of projects) to avoid runs will influence economic conditions that cause subsequent runs on itself or on other banks. Economic conditions before banking crises, although predetermined, are probably not exogenous to the real effects of bank failure.

Our model is a "real" model, based on consumption goods rather than financial assets. We view this as a strength of the model. To the extent that financial assets derive their liquidity ultimately from liquid real assets, our model is at the appropriate level of abstraction. It helps us focus on the real budget constraint that an economy has to face.

The mapping to an economy where deposits pay off in financial assets may be quite close in some cases. For instance, before the Federal Reserve was set up in the United States, currency was relatively inelastic in the short run, and depended on gold inflows and outflows from trade and external borrowing. Currency would then correspond to the consumption good, and activities involving gold flows would correspond to the projects in our model. The crisis of 1907, which has been attributed to a shortage of liquidity (see Friedman and Schwartz (1963)), led to the creation of the Federal Reserve, and a currency that was less explicitly linked to real activity. Even with a central bank, though, suppose deposits are denominated in foreign currency, and there is an aggregate amount the country can borrow (see Caballero and Krishnamurthy (2000) for a model of why there might be limits to aggregate borrowing). Then a reduction in this aggregate amount can trigger off a liquidity shortfall for the banking system, with many of the consequences we have described. We propose in future work to explore further the links between shortfalls of real goods and shortfalls of financial assets. 


\section{References}

Allen, F, and D. Gale[1998], “Optimal Financial Crises,” Journal of Finance 55.

Allen, F, and D. Gale [2000], “Financial Contagion,” Journal of Political Economy 108: 1-33.

Bagehot, W. (1873) Lombard Street.

Bernanke, Benjamin, 1983, Non-monetary effects of the financial crisis in the propagation of the great depression, American Economic Review 73, 257-276.

Bhattacharya, S. and D. Gale [1987], "Preference Shocks, liquidity and Central Bank Policy", in New approaches to monetary economics, edited by W. Barnett and K. Singleton, Cambridge University Press: Cambridge.

Boyd, John and Edward Prescott [1986], "Financial Intermediary Coalitions," Journal of Economic Theory.

Bryan, Lowell [1988]. Breaking Up The Bank : Rethinking an Industry Under Siege , Dow Jones-Irwin, Homewood, IL.

Bryant, John [1980], “A Model of Reserves, Bank Runs, and Deposit Insurance,” Journal of Banking and Finance, 4: 335-344.

Caballero, R, and A. Krishnamurthy [1999], "Emerging Market Crises: An Asset s Market Perspective," MIT Mimeo.

Caballero, R, and A. Krishnamurthy [2000], “International Liquidity Management: Sterilization Policy in Illiquid Financial Markets”, mimeo, MIT.

Calomiris, Charles W., and Gary Gorton (1991). "The Origins of Banking Panics: Models, Facts, and Bank Regulation." In Financial Markets and Financial Crises, edited by R. Glenn Hubbard, pp. 109-173. University of Chicago Press.

Calomiris, Charles W. and Charles M. Kahn [1991], “The Role of Demandable Debt in Structuring Optimal Banking Arrangements" The American Economic Review, Vol. 81, No. 3. (Jun., 1991), pp. 497513.

Diamond, D. W. [1984], "Financial Intermediation and Delegated Monitoring," Review of Economic Studies 51 (July): 393-414.

Diamond, D. W. [1991], "Debt Maturity Structure and Liquidity Risk," Quarterly Journal of Economics, (August).

Diamond, D. W. [1997], “Liquidity, Banks, and Markets,” Journal of Political Economy, 105 (October): 928-956.

Diamond, D. W. [1999], “Should Japanese Banks Be Recapitalized?” University of Chicago working paper.

Diamond, D. W. and P. H. Dybvig [1983], “Bank Runs, Deposit Insurance, and Liquidity,” Journal of Political Economy 91, 401-419.

Diamond, D. W. and R. G. Rajan [2000], “A Theory of Bank Capital,” Journal of Finance 55 (December): 2431-2465.

Diamond, D. W. and R. G. Rajan [2001a], "Liquidity Risk Liquidity Creation and Financial Fragility: A Theory of Banking," Journal of Political Economy 109 (April). 
Diamond, D. W. and R. G. Rajan [2001b], "Banks, Short Term Debt, and Financial Crises: Theory, Policy Implications, and Applications", forthcoming, Carnegie Rochester Conference on Public Policy, 54 (Summer).

Diamond D. W. and R. G. Rajan [2001c], "Banks and Liquidity," American Economic Review, Papers and Proceedings, 2001.

Diamond D. W. and R. G. Rajan [2002], "Bank Bailouts and Aggregate Liquidity” mimeo, University of Chicago.

Donaldson, Glen [1992], "Costly Liquidation, Interbank Trade, Bank Runs and Panics", Journal of Financial Intermediation, 2, 1, 59-82.

Friedman, M and A. Schwartz [1963], A Monetary History of the United States 1867-1960. Princeton: Princeton Univ Press.

Goodfriend, Marvin, and Robert G. King (1988) "Financial Deregulation, Monetary Policy, and Central Banking," Federal Reserve Bank of Richmond Economic Review, vol. 74 (May/June 1988), pp. 3-22.

Gorton, Gary, and George Pennacchi [1990]"Financial Intermediaries and Liquidity Creation", Journal of Finance 45: 49-71.

Hart, Oliver and John Moore, "A Theory of Debt Based on the Inalienability of Human Capital," Quarterly Journal of Economics, v109 n4 (November 1994), pp. 841-79.

Hart, Oliver, Firms, contracts, and financial structure, Oxford and New York: Oxford University Press, Clarendon Press, 1995.

Hellwig, Martin [1994], Liquidity Provision, Banking, and the Allocation of Interest Rate Risk, European Economic Review v38, n7 (August 1994): 1363-89.

Holmström, B. and J. Tirole [1997], "Financial Intermediation, Loanable Funds, and the Real Sector," Quarterly Journal of Economics, 52 (August): 663-692.

Holmström, B. and J. Tirole [1998], "Private and Public Supply of Liquidity," Journal of Political Economy 106 (February): 1-40.

Holmstrom, B. and J.Tirole [1999], Presentation notes, Conference on Liquidity at the LSE.

Jacklin, C. J. [1987], “Demand Deposits, Trading Restrictions, and Risk Sharing,” in: E. C. Prescott, N. Wallace (eds.), Contractual Arrangements for Intertemporal Trade, Minneapolis: University of Minnesota Press, 26-47

Jacklin, C. and S. Bhattacharya [1988], "Distinguishing Panics and Information-based Bank Runs: Welfare and Policy Implications", Journal of Political Economy, 96 (3) 568-592.

Kashyap, A., R. Rajan, and J. Stein [1999], "Banks as Liquidity Providers: An Explanation for the CoExistence of Lending and Deposit Taking”, mimeo, University of Chicago.

Kaufman, G. (1994), "Bank Contagion: A Review of the Theory and Evidence," Journal of Financial Services Research: 8 (April): 123-50.

Kiyotaki, N. and J. Moore (2000), “Inside Money and Liquidity,” working paper, LSE.

Myers, Stewart and Raghuram Rajan (1998), "The Paradox of Liquidity”, Quarterly Journal of Economics, August 1998, vol 113: (3), pp 733-771.

Qi, Jianping (1998), “Deposit Liquidity and Bank Monitoring”, forthcoming, Journal of Financial Intermediation. 
Rajan, R. [1992], "Insiders and outsiders: the choice between informed and arm's length debt", Journal of Finance 47, 1367-1400.

Simons, Henry [1948]. Economic Policy for a Free Society, University of Chicago Press Chicago, IL.

Smith, B.,1991, Bank panics, suspensions, and geography: some notes on the "contagion of fear" in banking, Economic Inquiry 29, 230-48.

Thornton, Henry . An Enquiry into the Nature and Effects of the Paper Credit of Great Britain (1802). Together with His Speeches on the Bullion Report, May 1811. F. A. von Hayek, ed. London: George Allen \& Unwin, 1939.

Wallace, N. [1988], "Another Attempt to Explain an Illiquid Banking System: The Diamond and Dybvig model with sequential service taken seriously." Federal Reserve Bank of Minneapolis Quarterly Review, Fall, 3-16. 


\section{$\underline{\text { Sketch of Proof of Lemma } 1}$}

Case 1: $1 \leq \mathrm{r}<\mathrm{R}$

The interest rate is bounded below at 1 by the rate on storage. If $r<\mathrm{R}$, the banker can raise the maximum funds at date 1 by continuing all late projects. He also maximizes his take by doing so. Therefore, if he cannot attract enough funding to continue all late projects, he has the incentive to bid the rate up a little higher so as to attract more funding. So if the equilibrium interest rate is less than $\mathrm{R}$, it must be that any solvent bank continues all late projects.

A solvent bank has to pay off both depositors and capital. From our earlier analysis, this amount is $\frac{v\left(\alpha^{i}, 0, r\right)+d_{0}}{2}$ where $d_{0}$ is the face value of deposits issued at date 0 . Therefore, a bank is solvent when $r<$ RSince the required payments to capital adjust with the value of the bank, any bank that can raise enough to meet deposits is solvent. Therefore, let $i^{*}(r)$ be such that $v\left(\alpha^{i^{*}}, 0, r\right)=d_{0}$. Then banks with $i \geq i^{*}(r)$ are solvent, while those with $i<i^{*}(r)$ are insolvent and will be run. ${ }^{22}$

Case 2: $R<r<\bar{R}$.

The banker prefers to continue but can raise more by restructuring late projects. The amount to be paid capital and deposits is now $\frac{v\left(\alpha^{i}, 1, r\right)+d_{0}}{2}$ (note that the pledgeable outside value is more if all late projects are restructured, so $\mathrm{v}$ for the purposes of determining what capital gets is now calculated as if all late projects are restructured). Therefore, a bank is solvent now if $i$

\footnotetext{
${ }^{22}$ Information is revealed before date 1, so runs will take place before any projects pay off. Even though no consumption goods are available then other than those obtained by restructuring projects, depositors do not really need to consume till date 1 . As a result, they will accept any claims that are sure to pay off at date 1 in lieu of cash. This means that banks that are expected to be solvent at date 1 can buy the date- 2 portion of restructured loans from insolvent banks by issuing fresh deposits to them. The insolvent bank will then turn over these deposits to its own depositors in lieu of cash. Since it is costless for solvent banks to issue deposits, and it is costless for depositors to wait to consume, the gross interest rate between the time information is revealed and date 1 is 1 .
} 
$\geq i^{*}(r)$ where $i^{*}(r)$ is such that $v\left(\alpha^{i^{*}}, 1, r\right)=d_{0}$. But even solvent banks may now restructure some projects. ${ }^{23}$ The fraction solvent bank $i$ will restructure will be the minimum non-negative $\mu^{\mathrm{i}}$ such that

$$
v\left(\alpha^{i}, \mu^{i}, r\right) \geq \frac{v\left(\alpha^{i}, 1, r\right)+d_{0}}{2}
$$

Case 3: $r \geq \bar{R}$

If the interest rate $\mathrm{r}$ reaches or exceeds $\bar{R}$, then banks will restructure all late projects. Solvent banks will have to pay out an amount equal to the right hand side of (1.13). Now let us proceed to the determination of the interest rate.

\section{Sketch of Proof of Proposition 2:}

At date 0 , the bank will choose the fraction invested in storage, $s_{0}$, as well as the quantity of deposits issued, $d_{0}$, per unit of resources raised. The bank will have to pledge out the maximum to investors in order to be able to raise money in the competitive market for funds. Start first by assuming the bank invests all resources in lending. Also, assume there is only one aggregate state at date 1 . The extension to when there are multiple aggregate states is straightforward.

For every deposit level $d_{0}$, there will be a date-1 equilibrium interest rate (if there are multiple equilibrium rates, we will assume the lowest one prevails), a marginally solvent bank, $i^{*}\left(d_{0}\right)$, and equilibrium decisions by solvent banks on how many of their late projects they will restructure, $\mu^{i}\left(d_{0}\right)$. It is straightforward to integrate across bank types to obtain the amount that will be paid out at date 1 to date- 0 investors at that level of deposits, $d_{0}$. Let this be $v_{1}\left(d_{0}\right)$.

Let $\quad d_{0}^{*}=\underset{d_{0}}{\operatorname{Arg} \max } v_{1}\left(d_{0}\right)$ s.t. $\frac{d_{0}^{*}}{v_{1}\left(d_{0}^{*}\right)}<\frac{1}{1+k}$. This is the value of deposits that maximizes payout subject to the bank's capital meeting the capital constraint. If $v_{1}\left(d_{0}{ }^{*}\right)>1$, then the maximum payout with the banks lending everything exceeds the maximum payout when the banks store everything.

Now it is easy to show that it is optimal for an individual bank to lend everything and to choose a deposit level of $d_{0}{ }^{*}$ when all other banks do so. Assume not. Let the bank store $1>s_{0}>0$. Let the

${ }^{23}$ The banker restructures loans only to meet his obligations at date 1 . He cannot restructure fewer loans by paying a higher interest rate to draw in more money (unlike in the previous case). Because the restructured loan is worth more in present value than a continued loan, he would not be able to meet his obligations if he tried to continue the loans. 
bank issue $\mathrm{d}^{\mathrm{s}}$ of deposits against the stored assets. Let it issue $\mathrm{d}^{\mathrm{L}}$ of deposits against the amount lent. Since the return from storage is certain, the spillover effect of storage, after it pays out on deposits issued against it, is as if the bank issued $\left(\mathrm{d}^{\mathrm{L}}-\left(\mathrm{s}-\mathrm{d}^{\mathrm{s}}\right)\right)$ of deposits against its loans (because the certain returns from storage can be fully offset against outstanding deposits, leaving net deposits as all that matters). But we know that the pledgeable amount from lending is maximized when the deposits issued against $\left(1-s_{0}\right)$ units of loans is $\left(1-s_{0}\right) d_{0}{ }^{*}$. Therefore, it must be that

$$
\begin{aligned}
& d^{L}-\left(s_{0}-d^{s}\right)=\left(1-s_{0}\right) d_{0}{ }^{*} \\
& =>d^{s}+d^{L}=s_{0}+\left(1-s_{0}\right) d_{0}{ }^{*}
\end{aligned}
$$

But the last equality implies that one can treat the value from storage as going completely to service the deposits issued against storage, and the value from the amount lent as going completely to service deposits and capital issued against the amount lent. Therefore, the pledgeable amount if the bank stores is

$$
s_{0}+\left(1-s_{0}\right) v_{1}\left(d_{0}^{*}\right)<v_{1}\left(d_{0}^{*}\right)
$$

where the last inequality is because $v_{1}\left(d_{0}^{*}\right)>1$. Thus the bank can pledge less than other banks if it stores, and will not attract funds. It will therefore not store. A similar line of argument explains why the bank will not lend if $v_{1}\left(d_{0}^{*}\right)<1$.

Q.E.D. 
Figure 1: Project Outcomes

$\mathrm{B}=$ Bank

$\mathrm{E}=$ Entrepreneur

$\mathrm{D}=$ Other outside investor

Date 0

Date $1 / 2$

Date 1

Date 2

State known

Banker and entrepreneurs consume

$\underline{\text { Project Outcomes }}$

Investment made

\section{If restructured}

Cash $=\mathrm{c}_{1}$ immediately

plus $\mathrm{c}_{2}$ at date 2 .

$\mathrm{B}$ or $\mathrm{E}$ can restructure, and

then anyone can collect.
Date-0 investors consume.
E finish: $=\mathrm{C}$

$\mathrm{B}$ replaces $\mathrm{E}:=\gamma \mathrm{C}$

Outsider replace $\mathrm{E}:=0$
E finish: $=\mathrm{C}$

$B$ replace E: $=\gamma \mathbf{C}$

Outsider replace $\mathrm{E}:=0$ 
Figure 2: Sequence of events in the economy.

Date 2
Date 0
Date $1 / 2$
Date 1

State known

Date-0 investors consume.

Banker and entrepreneurs consume

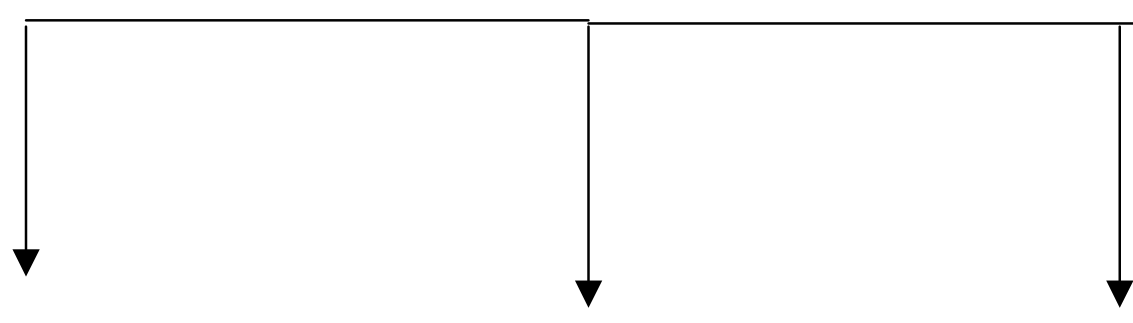

Banks raise money

competitively by issuing

deposits and capital to

investors. Money is lent

to entrepreneurs who

invest.

If a bank will be

insolvent at date 1 , its

depositors run. All

projects are

restructured.
Early entrepreneurs pay bank $\gamma \mathrm{C}$. They invest $(1-\gamma) \mathrm{C}$ in solvent banks or store. Solvent bank i restructures $\mu^{\mathrm{i}}$ late projects and continues the rest. Date- 0 depositors and capital are paid. Banker invests any excess cash in other banks.
Late entrepreneurs pay bank $\gamma \mathrm{C}$.

Bank pays date-1 depositors and capital (the early entrepreneur or 
Figure 3: Liquidity supply and demand as functions of interest rate, $r$

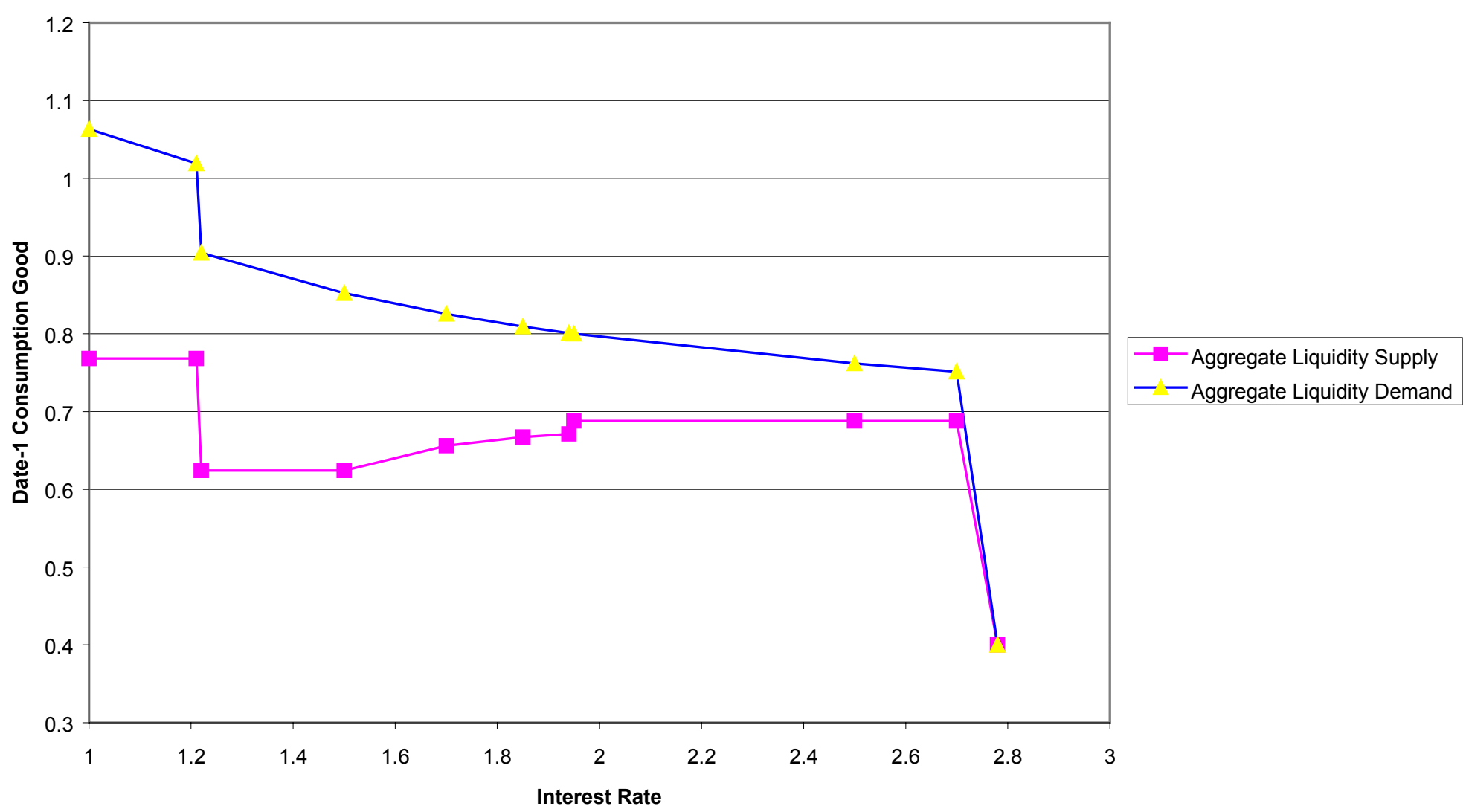

